\title{
The Subaerial and Freshwater Algal Flora of the Tropics.
}

\author{
A Phytogeographical and Ecological Study.
}

\author{
BV \\ F. E. FRITSCH, D.Sc., PH.D., F.L.S. \\ Assistant Professor of Botany, University of London, University College.
}

\section{INTRODUCTORY.}

F VER since Botany became an independent science the tropics have I attracted numerous specialists, who have dealt with one or other aspect of the tropical flora. These regions of the world provide so many striking problems, that many of them, although subsequently recognized as evident enough in our parts of the world, were first noticed and studied in the tropics. The science of ecology in particular received its first stimulus from tropical observation, and until quite recent years we were better informed about the conditions of vegetation in many parts of the tropics than in our own country. At a fairly early period we find botanists devoting a little attention to the tropical algal flora, but the apparent similarity between the freshwater Algae of the tropics and those of our parts did not encourage extensive observation in view of the numerous more striking problems to be solved. It was only in the seventies and eighties of the last century that a marked tendency became evident to collect more extensive data regarding tropical Algae, and this has since then led to the publication of quite a number of algal floras from diverse parts of the tropics. The latter are mainly due to the labours of Nordstedt, Lagerheim, W. and G. S. West, Schmidle, Möbius, De Wildeman, and Lemmermann, although, as the bibliography at the end of this paper will show, a large number of botanists are responsible for occasional papers on this subject.

The general result of this work has been to show that there is a great degree of similarity between the algal flora of the tropics and that of other parts of the world. This is indeed what was to be expected in view of the fact that most of the Algae belong to the biological group of aquatics, and

[Annals of Botany, Vo1. XXI. No. LXXXII. April, 1907.] 
are, therefore, subject to much the same conditions in all parts of our globe ${ }^{1}$. But in spite of this uniformity of conditions, which is too obvious to need further comment, there are considerable minor diversities, which have been overlooked or not adequately considered, and no attempt has been made to correlate them with any peculiarity of the algal growth in different regions. Moreover, as regards the subaerial algal vegetation the influencing factors are markedly different in the tropics to those existing in our parts of the world, and here we have a much more fundamental and obvious difference in character. It is my object in the present paper to attempt an analysis of the existing data on tropical freshwater and subaerial Algae with the help of certain observations made in Ceylon. I hope to be able to show that the apparent similarity of algal growth all over the world is not quite as great as is generally imagined.

Very few of the existing tropical algal floras can be regarded as in any way representative of the region they deal with. Many of them are merely records of the occurrence of a few species in a certain district, and even the more extensive ones show marked signs of being incomplete in one direction or other. They are nearly all the result of casual collections made by botanical travellers occupied in the investigation of other problems, and the only exceptions are those of Welwitsch, Hansgirg, and De Wildeman. The two latter are, as far as I am aware, the only algologists who have had opportunities of collecting in person in the tropics, and even they were occupied with other investigations at the same time, and did not devote their whole attention to the algal flora. None of the existing floras aim at giving a true picture of the algal vegetation. They, of course, give us a record of a larger or smaller number of algal species found in a certain district, but they tell us nothing about the relative abundance in individuals of these species. The specific lists are of little use from this point of view, for, although a flora may include only a small specific element of a certain group, the number of individuals may be very great, and the group may play a very important part in the algal vegetation. Little blame attaches to the specialists who have worked out the collections, but one cannot suppress a certain amount of disappointment at the remissness of the collectors themselves in this respect. And this is not the only criticism that they call forth, for one misses in most of the floras adequate data as to locality and habitat, without which a flora becomes practically useless except from the geographical point of view. In very many cases the only information as to locality given is furnished by a mention of some province or town. Even some of the algologists do not appear to realize the necessity of as complete data as possible on these points (Turner, '92). I cannot in the very least agree with Schmidle ('00 A, p. I60) when he says: 'Es ist doch für die Wissenschaft völlig 
gleichgültig, die genauen zufälligen Standorte solcher Ubiquisten zu kennen.' I think it very unlikely that for many of the forms enumerated by him without any mention as to locality that the latter is at all 'zufällig' (cf. also below). In view of these facts it is very difficult in most cases to obtain the kind of information we want from the tropical floras. I may take this opportunity of urging the importance of careful notes on relative abundance of species and habitat to all algal collectors, and more particularly to those who do not work out the results of their own collections, but pass them on to specialists for investigation. There is one other feature that it is well to pay attention to during the compilation of a flora, and that is the usual associates of certain forms to be considered in greater detail below. Data of this kind are to be found in a number of algal floras, but one completely misses them in others. And yet such data are hardly less important in aiding one to call up a picture of the algal vegetation of a given district than the relative abundance of the different species.

The subsequent remarks are based on the records contained in the literature enumerated at the end of this paper, and are supplemented and originally stimulated by observations made in Ceylon. The bibliography does not pretend to be absolutely complete, but I think that all the more extensive papers are included, and also all the smaller ones containing data bearing on the present subject. Only such papers are included as deal either entirely or partly with the flora of regions situated between the tropics of Cancer and Capricorn. This limitation is of necessity somewhat artificial, but I saw no other way of drawing a boundary.

In the course of the subsequent considerations it has frequently been necessary to enumerate all the records of a genus or group of genera. I have endeavoured to make these lists as complete and as accurate as possible in the hope that they may not only prove of service from the point of view of the present paper, but also as an epitome of our present knowledge of the distribution of these forms in the tropics. On the whole I have, however, refrained from dealing with these records critically, as such a treatment would have necessitated a much greater extension of this paper than seemed advisable.

\section{The Systematic Composition of the Subaerial Algal}

FLORA OF THE TROPICS.

I have already elsewhere ${ }^{1}$ pointed out the very different character of the subaerial algal vegetation in the tropics and in our parts of the world. The difference not only concerns the relative extent of development, but also the specific composition. With reference to the former point, my experience is gained from observation in the damp districts of Ceylon,

1 Proc. Roy. Soc., Ser. B, vol. lxxix, 1907. 
where the abundance of the subaerial algal covering is truly striking. I have no doubt that, wherever in other parts of the tropics the two necessary factors (temperature and moisture) combine, there exists a similar abundance of subaerial Algae. The literature indeed affords very few data to go upon. The few really extensive, and to some extent apparently complete, tropical algal floras do indeed enumerate a considerable number of subaerial Algae (see especially De Wildeman, '00; Gomont, '02 ; West and West, '93 and '97 A), but, as above mentioned, they give no data as to extent of occurrence. The only positive statement that I know of is as follows: Welwitsch ${ }^{1}$ describes the prolific growth of a blue-green Alga, Scytonema.chorographicum, Welw. (= S. Myochrous (Dillw.), Ag. var. chorographicum, W. and G. S. West), on the mountains of Pungo Andongo in Angola; this Alga causes a characteristic feature of the country, since it gives rise to a black colouration on these mountains (hence locally known as 'pedras negras' or black rocks) (cf. W. and G. S. West, '97 A, p. 3०3) 2. Another 'Scytonema' (= Porphyrosiphon Notarisii, Kütz.) plays an equally important part, according to Welwitsch, in the damp sands of the upper valley of the Cuanza River, where it 'frequently extends across the wide meadows, closely spread like a net over the soil, intergrown with the other herbs and smaller shrubs.' A perusal of Gomont's account of the Myxophyceae hormogoneae collected by the Danish expedition to the Gulf of Siam (Gomont, '01, p. 202 et seq.) also tends to show that there is a considerable subaerial algal element in these regions. The same impression is gained if we look over the records of Cyanophyceae in De Wildeman's algal flora of Buitenzorg (De Wildeman, '00). Other data in support of this view are given in the table on p. 244. As will be seen, there is little direct evidence to go upon, but it is sufficient to show that in all probability all damp tropical regions harbour a rich subaerial algal vegetation ${ }^{3}$.

An examination of the abundant algal covering in the damp lowlands of Ceylon showed that it was practically entirely constituted by members of the Cyanophyceae (Myxophyceae). I have elsewhere ${ }^{4}$ dealt with the many interesting biological peculiarities of this Cyanophyceous growth, and we are here only concerned with the systematic and phytogeographical sides of the question. There is practically no green element in the subaerial algal flora of the Ceylon lowlands (except Trentepohlia, see below, p. 242), the only marked exception observed being the growth on the subaerial portions of the stilt-roots of the mangroves at Kalutara (a form

1 Welwitsch, Journal of Travel and Natural History, vol. i, 1868, pp. 22 et seq.

2 Cf. also Warming, Ökologische Pflanzengeographie. German Edit., Berlin, 1896, p. 2 I 5 .

${ }^{3}$ It is of course not impossible that under exceptional conditions even damp tropical regions may be poor in subaerial algal growth. Lemmermann ('05, p. 609) found very few aerophilous forms in his material from the Sandwich Islands, but it is open to question as to whether this is not due to imperfect collecting.

${ }^{4}$ Proc. Roy. Soc., Ser. B, vol. lxxix, 1907. Section $a$ of this paper deals with the subaerial Algae (cf. also a forthcoming paper in the Geographical Journal, vol. xxix, 1907). 
like Pleurococcus); but even here numerous Chroococcaceous colonies were intermingled, and threatened ultimately to completely crowd out the green forms. Occasional colonies of green forms in very subordinate amount are sometimes to be found amid the elements of the blue-green growth, but their number is so small that from a general point of view they are negligible. The great preponderance of blue-green forms is no doubt in part due to special favouring conditions (high temperature, humidity of the air), but in part also to the dominant factors in the tropics (intense light, frequency of and extreme degree of desiccation) being unsuitable to the growth of pure green forms. Light probably plays a great part in the exclusion of the latter, the successful blue-green element having a protective pigment in the form of the phycocyanin, which accompanies the chlorophyll in the cells.

We will now examine the literature with reference to this point. The statements quoted on p. 238 illustrate the fact that such records of an abundant occurrence of subaerial Algae in the tropics as exist refer to Cyanophyceae. All the more extensive algal floras show a relatively very large blue-green element, although no one actually mentions the dominance of the latter group in the subaerial vegetation ${ }^{1}$. An analysis of the tropical floras from this point of view will be found on p. 244, and it is unnecessary to say more on this subject here. The following is a list of the more important records of the occurrence of green subaerial forms in the tropics :-

I. Pleurococcus crenulatus, Hansg.-Schmidle, '97 E, p. ${ }^{2} 5^{8}$ ('Am Holze der Regenrinnen, Savaii. Das getrocknete Zellager ist gelblichgrün'); Lagerheim, '90, p. 6 (on branches of Ilex scopulorum).

2. Pleurococcus Kützingii, West.-West, '04, p. 287 ('Barbados.-Bay Estate ; forming a yellow-green stratum about I $\mathrm{mm}$. in thickness, with a species of Lyngbya').

3. Pleurococcus miniatus (Kütz.), Nägeli.-Lagerheim, ’90, p. 6 ('En las piedras húmedas en el jardín botánico').

4. Pleurococcus vulgaris, Menegh.-West, '04, p. 287 ('Barbados. - Bay Estate') ; De Wildeman, '97, p. 80 (Jard. bot. de Buitenzorg); West and West, '02 в, p. 200 ('On decomposing surface of gneiss, Matara'); Möbius, '95, p. 175 ('An einem Felsenabhang, Tubarão'); De Wildeman, '00, p. Io9 ('Sur les écorces d'arbres, sur les murs, etc. -Jardin bot. de Buitenzorg'); Zeller, '73, p. I 84 ('Rangoon, ad parietes hospitii “circuit house" dicti'); Hieronymus, '95, p. 22 (no habitat mentioned); Lagerheim, '90, p. 6 (tree-trunks); Bohlin, '97, p. I 2 (Paraguay).

5. Protococcus botryoides (Kütz.), Kirchn.-West and West, ' 97 A, p. 239 ('Loanda. A light-green cover, often remaining dry, on the inner part of wooden water reservoirs').

${ }^{1}$ Lemmermann ('05, p. 609) comments on the absence of Hormidium and Pleurococcus from the subaerial algal flora of the Sandwich Islands. 
6. Protococcus caldariorum, Magn.-Schmidle, '00 D, p. 8 (on leaves of trees, \&c. ; probably a stage in development of various Chroolepideae).

7. Protococcus cinnamomeus, Kütz.-Schmidle, '00 A, p. I6 I (no locality given).

8. Protococcus cohaerens, Kütz.-Prain, '05, p. $3^{29}$ (damp walls).

9. Protococcus viridis, Ag.-Schmidle, '00 A, p. I6I (no locality given); West and West, '97 A, p. 239 ('Loanda. Ad parietes domorum, \&c., saepius humectatas in ipsa urbe Loanda, ast sparsim. Locus habitationis huius algae austrum versus spectat ') ; Dickie, '81, p. 125 ('Damp wood at Tabatinga, and at Serpa ') ; Schmidle, '97 E, p. $25^{8}$ ('Auf faulendem Holz, dunkelgrün, Matautu, Savaii') ; Lagerheim, '90, p. 4 (on trunks of Prunus salicifolia, H. B. K.).

ı. Stichococcus bacillaris, Nägeli.-Lagerheim, '90, p. 5 ('En los muros húmedos en el jardín botánico y en otros lugares en Quito ').

I I. Stichococcus flaccidus (Kütz.), Gay.-West and West, '97 A, p. 239 ('Loanda. Inter Prolococcum botryoidem (Kütz.), Kirchn.').

1 2. Urococcus insignis (Hass.), Kütz.-West and West, '97 A, p. 239 ('Huilla. In paludibus exsiccandis '); West and West, '93, p. 268 (on mossy trees, summit of Trois Pitons (4,500 ft.), Dominica).

I3. Cerasterias staurastroides, W. and G. S. West.-West and West, '93, p. 268 (with Scytonema javanicum, Bornet, amongst mosses on lime-trees, Shanford Estate, Dominica).

14. Gloeocystis gigas (Kütz.), Lagerh.-West and West, '99, p. 285 (' On trees in woods round Roseau Lake, Dominica ; with Oocystis solitaria, Wittr.).

I5. Glococystis rupestris (Lyngb.), Rabh.-West and West, '97 A, p. 239 ('Pungo Andongo. Alga terrestris, ad ligna putrescentia in rupibus convallibus ').

16. Hormidium murale, Kütz.-Schmidle, '00 A, p. I6o (no locality given).

See also Rhizoclonium crassipellitum, W. and G. S. West (p. 250 ), and $R$. spongiosum, Dickie (p. 25I). Regarding Trentepohlia, see below, p. 242; terrestrial species of Vaucheria, p. 254.

This list shows that the records of green forms in the subaerial vegetation are meagre, especially when compared with the often very numerous records of subaerial blue-green forms (cf. table, p. 244). Moreover, such data as to habitat as are given point, at least in some cases, to some sort of protection against illumination ; I have indicated such points by placing the words in black type, and do not think it necessary to offer further comment upon them at present.

The dominance of the Cyanophyceae in the subaerial algal vegetation of the tropics is thus manifest, and I cannot doubt that in other damp tropical parts they will be equally and perhaps even more strikingly developed than they are in Ceylon. A visit to any moist and hot greenhouse shows exactly the same thing, viz. great development of subaerial algal growth, which is almost purely blue-green. Everything points to most of the subaerial Cyanophyceae being more at home in a moist, hot atmosphere than in a cold one. Subsequent considerations will show that 
the group of the blue-green Algae also plays a great part in the aquatic algal flora of the tropics (cf. p. 243). Amongst all the different groups of Algae probably none present so many unique features as do the Cyanophyceae. It is only necessary to recall the complicated cytology, the curious structure of the investment, the very characteristic propagation by means of motile filaments or hormogonia, and the peculiar heterocysts found in so many members of the group. Extensive study of the Cyanophyceae leads one to the gradual conviction that one is dealing with a very ancient phylum of the vegetable kingdom, which has in part retained a number of primitive features, although along other lines it has become highly specialized. There is little fossil evidence in support of this point of view, but so little is known about fossil Algae generally (except some of the calcareous forms) that the absence of such evidence cannot be regarded as in any way a proof against the ancient character of a group. A few doubtful fossils (e.g. Zonatrichites, Bornemann, and Gloioconis Borneti, Renault) have been referred to Cyanophyceae, and certain oolitic structures have been regarded as the result of the activity of members of this group, but these data are very fragmentary. Seward ${ }^{1}$ discusses their possible presence in former periods as follows: 'Although our exact knowledge of fossil Cyanophyceae is extremely small, it is probable that such simple forms of plants existed in abundance during the past ages in the earth's history. Several writers have expressed the opinion that the blue-green Algae may be taken as the modern representatives of those earliest plants which first existed on an archaean land-surface. The living species possess the power of resisting unfavourable conditions in a marked degree, and are able to adapt themselves to very different surroundings. Their occurrence in hot springs proves them capable of living under conditions which are fatal to most plants, and suggests the possibility of their occurrence in the heated waters which probably constituted the medium in which vegetable life began ${ }^{2}$ ' In view of the exceeding abundance of this group of Algae in the tropics one can scarcely resist the assumption that their habitats in these regions are more in accord with their former conditions of existence than the habitats of temperate regions. A considerable number of Cyanophyceae have indeed become acclimatized to the changed conditions in these latter parts of the world, but the group is certainly prevalently tropical. Moreover, it was only in the damp tropics that many forms were able to leave the water and live a more or less terrestrial life; after all, the tropical subaerial habitats are semi-aquatic in the conditions they offer. The abundance of the blue-green group in the tropics is not the only evidence for the view that these regions of the world are more like their habitats in former epochs of the earth's history.

${ }^{1}$ Fossil Plants, vol. i, Cambridge, 1898, p. I3 I.

${ }^{2}$ Cf. also Warming, Ökologische Pflanzengeographie. German Edition, Berlin, I8g6, p. I $5^{8}$. 
In other respects also the Cyanophyceae show indications of being more favourably situated there. The heterocysts, in particular, point to such a conclusion, for in the greater portion of my material from Ceylon they show well-developed contents, often even coloured a deeper blue than the contents of the ordinary vegetative cells (e.g. in species of Rivularia ${ }^{1}$ ). The tropics no doubt afford a much more suitable field for the investigation of the bluegreen group than do our parts of the world, and many of the problems connected with this group may find an adequate solution in the investigation of tropical material. It further does not seem at all unlikely that many of the Cyanophyceous forms of the tropics may pass through a more complete life-cycle than in the less favourable conditions of temperate regions. As an outcome of these considerations we may state that the Cyanophyceae are probably a group originally adapted to tropical conditions, and that there is some slight evidence for the view that they are the descendants of primitive algal forms, which flourished in earlier epochs of the earth's history under conditions somewhat similar to those obtaining in the damp tropics at the present day.

In talking of the minimal development of green forms in the subaerial algal flora of the tropics, the genus Trentepohlia was stated to be an exception. Species of this genus indeed play a great part in subaerial tropical vegetation ${ }^{2}$, a statement based not only on my own observations in Ceylon, but also on the abundant records in the literature (cf. especially Karsten, '91 ; De Wildeman, '91, '94, '97, and '00; West and West, '02 B ; Zeller, '73; Hariot, '89 and '92). The yellowish-red tufts or tresses of Trentepohlia are very abundant amidst the sombre Cyanophyceous growth in Ceylon, and form an agreeable interruption to its monotony. There can be little doubt that it is the screening action of the haematochrome in the cells of this genus that makes it alone successful amongst all the green forms, and this also points to intensity of illumination as being one of the most important factors excluding green forms from tropical subaerial habitats ${ }^{3}$. A very large number (about 40 ) of species of Trentepohlia have been described from the tropics, and in most cases the number of records is quite considerable (see also table on p. 244). Although so successful in the tropics, there seems no reason at present for looking upon this genus as essentially tropical; quite a large number of species are found in temperate regions, generally in well-illuminated habitats (especially abundant in alpine regions).

The abundant moisture in the damp tropics not only leads to the development of a very rich subaerial algal growth on tree-trunks, rocks,

${ }^{1}$ Cf. Fritsch, Studies on Cyanophyceae II. Beih. Bot. Centralbl., Bd. xviii, Abt. I, I905, p. 207 , footnote 2 .

2 Lemmermann ('05, p. 609) states that Trentepohlias are wanting in the subaerial flora of the Sandwich Islands.

${ }^{3}$ Cf, also Fritsch, Proc. Roy. Soc., Ser. B, vol. lxxix, 1907. 
walls, \&c., but has also stimulated an epiphyllous tendency in many of the subaerial forms. Apart from epiphyllous Lichens and Liverworts, of the existence of which probably every one is familiar, we find a number of bluegreen and green forms growing on the leaves of the higher tropical vegetation (cf. especially Schmidle, '97 c, '97 D, '97 F, and '98 B; Möbius, '88; Raciborski, '00). The blue-green forms are in great part the same as are met with in the general subaerial growth, and it is easy to comprehend how they invade moisture-covered leaves from neighbouring subaerial habitats. This phenomenon can be readily observed in the Nepenthes-house at Kew, where diverse blue-green forms settle down on the leaves of the plants cultivated there. The green forms, however, which have acquired the epiphyllous habit are on the whole much more specialized. They are all members of the Chroolepideae, the chief genera being Cephaleuros, Mycoidea, Phycopeltis, Phyllactidium, and Phylloplax (literature-Cunningham, '80; De Toni and Saccardo, '90; De Wildeman, '00 ; Karsten, '91 ; Möbius, '88 ; Raciborski, '00; Schmidle, '97 c, '98 B, '99; Ward, '84). Their structure is adapted to their mode of life, and like the species of Trentepohlia, their cells contain a yellow or red colouring matter, which exerts a screening action on the chlorophyll. The genera Phyllosiphon. and Phytophysa (see especially De Wildeman, '00; Lagerheim, '92; and Raciborski, '00) have gone still further, since they penetrate the tissues of their substratum and lead a parasitic life. These diverse cases are of the utmost interest as showing the range of possibilities afforded by life in tropical subaerial habitats.

\section{The Systematic Composition of the Submerged Aquatic Algal Flora of the Tropics.}

A careful study of the freshwater algal flora of the tropics, such as I was able to undertake in Ceylon, brings out two points, viz.: $(a)$ the dominance of the blue-green group, especially in the larger pieces of water, and $(b)$ certain peculiarities of the green algal vegetation when considered as a whole. In dealing with the general characters presented by the submerged algal growth of the numerous (often large) freshwater tanks of Ceylon, I summarized my observations by stating ${ }^{1}$ that ' whenever there is a well-developed algal flora in the considerable number of Ceylon tanks and lakes I have examined, there is always a noticeable blue-green element which very frequently dominates the entire algal growth.' The observations on which these conclusions are based are given in some detail in my paper on the general character of the freshwater algal flora of Ceylon (Fritsch, loc. cit.), and it will be sufficient to mention that of 46 tanks investigated 18 were absolutely dominated by Cyanophyceae with practically no green algal growth, while of the remainder 16 contained quite a considerable mass of 
blue-green vegetation. As a general rule the smaller the dimensions of a tank the less pronounced is the blue-green element found to be. In other types of Ceylon freshwaters the dominance of the Cyanophyceae was equally pronounced (rock-pools and, to a less extent, the rice-fields) or not so marked (small pools and ditches, and especially wells). The prevalence of this group is no doubt, again, due to the high temperature of the water and the intensity of illumination. The importance of the former factor is recognized by a comparison between the lowlands and uplands of Ceylon, the latter having an aquatic flora in which the blue-green element is almost as casual as it is with us. The influence of the intense light is shown by the minor part played by the Cyanophyceae in the smaller waters, which are often more or less shaded by surrounding vegetation.

\section{Table to show the Average Composition of Tropical Freshwater and Subaerial Floras.}

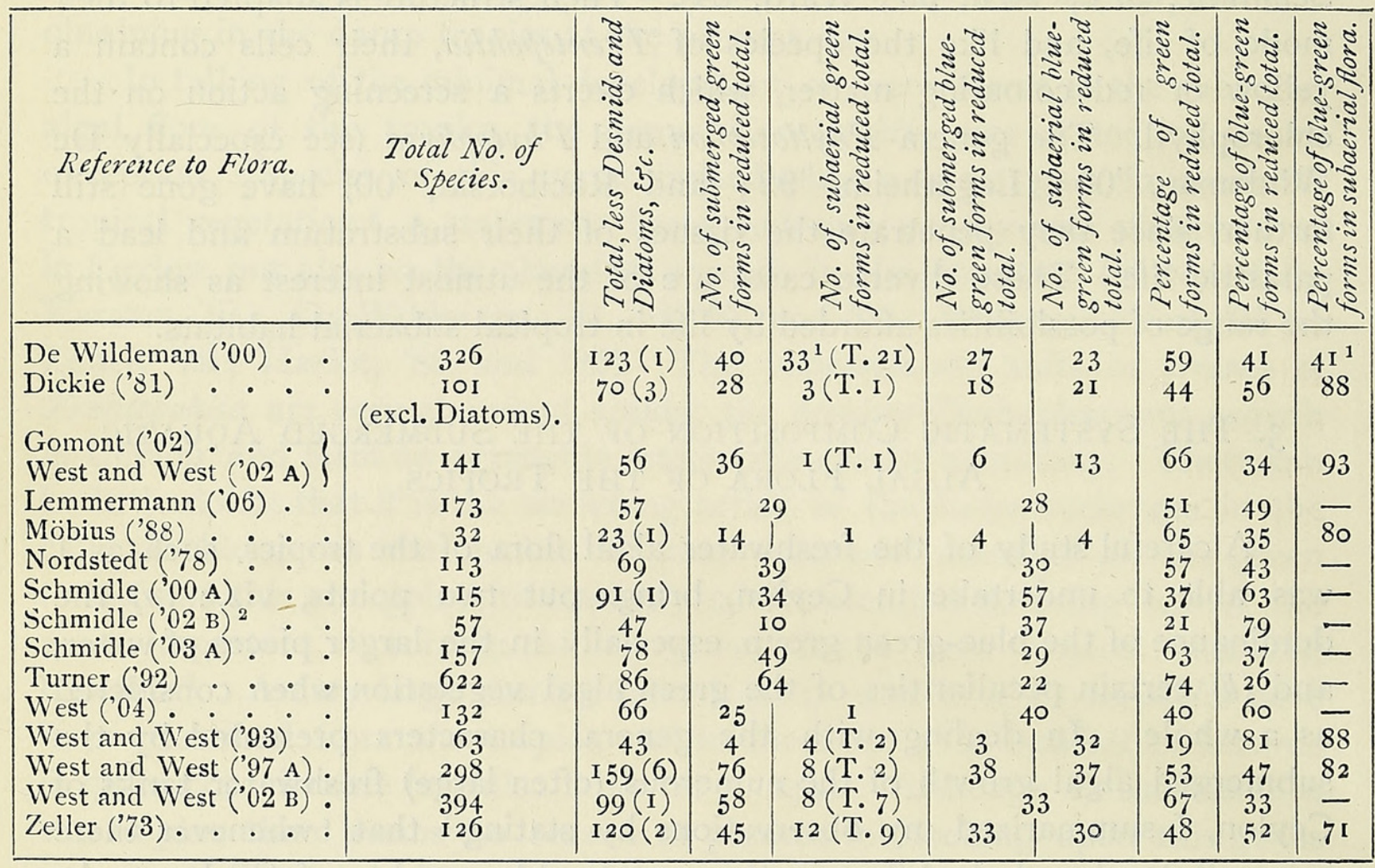

I am not aware of any direct statement in the literature as to the dominance of Cyanophyceae in the freshwaters of the tropics, although I feel convinced that Ceylon cannot be exceptional in this respect. Moreover a consideration of the few relatively complete floras that we possess distinctly points to this group being an important one in all parts of the

1 The large number of subaerial green forms (even when the 2 I Trentepohlias are excluded) is due to the enumeration of a considerable number of forms (belonging to Chroolepideae) found growing on leaves (cf. p. 243).

${ }^{2}$ A large number of the forms involved in this case are from hot springs, 
tropics. The table on the preceding page is an analysis of the data in a number of these floras with reference to this point. The numbers, of course, only refer to species; there is no means of finding out the numbers of individuals. This is unsatisfactory, but it does show certain points. Since the smaller unicellular and colonial forms are as a rule quite subsidiary to the larger ones, I have thought it well, in order to get a better idea of the systematic composition of a flora, not to include the Desmids, Diatoms, Peridineae or Flagellates in these calculations.

In explanation of this table I have still to mention that the few freshwater species of Florideae have been included amongst the green submerged forms in order to avoid undue complication; where there are records of such forms the number of species is added in brackets after the reduced total (in the second column). Since the species of Trentepohlia are often a considerable increment in the green subaerial flora, their number has been indicated in brackets behind the actual total, in the fourth column (preceded by the letter $\mathrm{T}$, which stands for Trentepohlia). In many cases the habitatdata were not sufficiently precise to enable one to distinguish between submerged and subaerial forms, so that the green and blue-green forms could only be included as a whole ; in these cases it was, of course, impossible to give a percentage in the last column. All marine forms have been excluded. The percentages are calculated to the nearest whole number.

Before proceeding to discuss the features illustrated by this table, we will just take three European freshwater algal floras for comparison. For this purpose I have selected Messrs. W. \& G. S. West's Freshwater Algae of the South of England ${ }^{1}$; Börgesen's Freshwater Algae of the Faeroes ${ }^{2}$; and Borge's Beiträge zur Algenflora von Schweden ${ }^{3}$. They illustrate the flora of regions which are sufficiently far apart and diverse in all except the temperate climatic conditions, and so there can be no fear of our dealing with a local aspect of European algal vegetation. Any other algal flora from our parts would give practically the same results as these do.

\section{Table to show Average Composition of Freshwater Algal GROWTH IN THREE EUROPEAN FLORAS.}

\begin{tabular}{|c|c|c|c|c|c|c|}
\hline Flora. & $\begin{array}{c}\text { Total } \\
\text { No. of } \\
\text { Species. }\end{array}$ & $\begin{array}{c}\text { Total, less } \\
\text { Desmids, } \\
\text { Diatoms, } \\
\text { Ec. }\end{array}$ & $\begin{array}{l}\text { No. of green } \\
\text { forms in re- } \\
\text { duced total. }\end{array}$ & $\begin{array}{l}\text { No. of blue- } \\
\text { green forms } \\
\text { in reduced } \\
\text { total. }\end{array}$ & $\begin{array}{c}\text { Percentage of } \\
\text { green forms } \\
\text { in reduced } \\
\text { total. }\end{array}$ & $\begin{array}{l}\text { Percentage of } \\
\text { blue-green } \\
\text { forms in re- } \\
\text { duced total. }\end{array}$ \\
\hline W. and G. S. West & $5^{88}$ & $255(2)$ & IS & $6 I$ & $7^{6}$ & 24 \\
\hline Börgesen . & $3^{23}$ & I 48 (I) & IO & $4^{I}$ & $7^{2}$ & 28 \\
\hline Borge & $47^{2}$ & I9I $(I)$ & I 49 & 42 & 78 & 22 \\
\hline
\end{tabular}

1 Journ. Roy. Microscop. Soc., I897, p. 467 et seq.

2 Botany of the Faeröes. Pt. I, Copenhagen, I90I, p. I 98 et seq.

${ }^{3}$ Arkiv för Botanik, Bd. 6, No. I, I906. 
It will be seen that the three floras from temperate regions show on the whole a considerably smaller percentage of blue-green forms than do the tropical floras ; most of the exceptional cases among the latter (viz. Möbius, '88; Turner, '92 ; West and West, '02 B) are confessedly unrepresentative collections. Moreover, we must guard against attributing too much value to these figures, for they mean only relative abundance of species, and we know nothing about individuals. But the table of tropical floras does quite unmistakably seem to point to the Cyanophyceae being a very important constituent of the algal flora in all parts of the tropics (cf. also, for instance, the relative numbers of blue-green forms as compared with the total number of species in the two tables).

Not only is the blue-green element of great importance in the submerged macrophytic growth of tropical freshwaters, but it also plays a very important part in the Plankton. More than half of the large pieces of water in Ceylon, whose Plankton I examined, abounded in floating microscopic Cyanophyceae (especially Clathrocystis), which in many cases indeed were the sole components of the Phytoplankton. Reference to the literature, again, shows that Ceylon is in no way exceptional in this respect (cf. Schmidle, '03 A and '04 A ; Lemmermann, '06, p. I47). I prefer, however, to defer further discussion on this subject, as I hope at an early date to deal with the Plankton contained in my collections from Ceylon.

The Cyanophyceae are a group of narrow forms, the diameter of the filamentous species rarely exceeding $5 \mu$, and very frequently being considerably less. That is a feature which may be of some advantage in water which is as poorly aerated as the ordinary tropical freshwaters are (cf. p. 252). A narrow filament will be better situated as far as gaseous exchange by diffusion is concerned than a broad one, and we may consequently expect that narrow forms will be more successful in the tropics than broad ones. As a matter of fact the entire freshwater algal flora of the tropics shows a preponderance of narrow forms. This is especially striking in the case of Oedogonium (cf. p. 265), a very important form in the green algal vegetation. The general prevalence of narrow forms is also due to absence or great scarcity of characteristic genera with broad filaments (Vaucheria, Cladophora). There are, however, two genera (Spirogyra, Pithophora) which furnish a considerable broad-celled contingent to the tropical aquatic algal flora, and of these Spirogyra is even highly abundant. This genus apparently gets on well in very poorly aerated water, whilst most of the freshwater algal genera have their broader representatives excluded from ordinary tropical freshwaters, or (probably) only developed under special conditions. This subject is discussed more fully in the following paragraphs. Confirmation for these theories must, of course, be sought in experiments, which will be undertaken in the near future.

Before concluding this section on the part played by the Cyanophyceae 
in the tropics, I will give a list of the blue-green (subaerial and freshwater) genera as yet known to occur in these parts of the world. The number in brackets after each genus refers to the approximate number of species recorded; I should have liked to have given a full list of species and records, but space does not allow of that. Literature references are only given in the case of new genera. The genera are arranged according to Kirchner's classification (in Engler and Prantl, Die naturlichen Pflanzenfamilien, I. Teil, Abt. I a, I900, p. 45 et seq.) :-

I. Chroococcaceae:-Chroococcus, Nägeli (I 7); Synechococcus, Nägeli (2); Glococapsa, Kütz. (I 5) ; Placoma, Schousboe (I); Glooothece, Nägeli (5); Aphanocapsa, Nägeli (4); Aphanothece, Nägeli (9); Microcystis, Kütz. (6); Clathrocystis, Henfrey (2); Gomphosphaeria, Kütz. (I); Coelosphaerium, Nägeli (4); Merismopedia, Meyen (6); Pilgeria, Schmidle (n. gen. in Schmidle, '01 A, p. 53); Tetrapedia, Reinsch (1о).

II. Chamaesiphonaceae :-Xenococcus, Thuret (I); Dermocarpa, Crouan (I); Chamaesiphon, A. Braun et Grunow (incl. Sphaerogonium, Rostaf.) (8).

III. Oscillatoriaceae:-Oscillatoria, Vauch. (28); Arthrospira, Stitzenberger (I); Spirulina, Turpin (1о); Phormidium, Kütz. (22); Proterendothrix, W. and G. S. West (n. gen. in West and West, '97 A, p. 299); Lyngbya, C. A. Agardh (24); Hypheothrix, Kütz. (го); Symploca, Kütz. (8); Porphyrosiphon, Kütz. (I); Hydrocoleum, Kütz. (3); Inactis, Kütz. (2); Schizothrix (Kütz.), Gom. (I6); Polychlamydum, W. and G. S. West (n. gen. in West and West, '97 ^, p. $27 \mathrm{I}$ ) ; Dasygloea, Thwaites (I); Microcoleus, Desmazières (6).

IV. Nostocaceae:-Nostoc, Vauch. (20); Nodularia, Mertens (2); Anabaena, Bory (incl. Sphaerozyga, Ag.) (I 2) ; Cylindrospermum, Kütz. (6); Aulosira, Kirchner (I); Microchaete, Thuret (I); Desmonema, Berkeley and Thwaites (I).

V. Scytonemataceae:-Plectonema, Thuret (5); Scytonema, C. A. Agardh (40); Tolypothrix, Kütz. (14).

VI. Stigonemataceae:-Mastigocladus, Cohn (2); Chondrogloea, Schmidle (n. gen. in Schmidle, '02 в, p. 247) (2); Hapalosiphon, Nägeli (13); Fischerella, Gomont (I); Stigonema, C. A. Agardh (I4); Camptylonema, Schmidle (n. gen. in Schmidle, '00 A, p. I8I); Capsosira, Kütz. (I); Nostochopsis, Wood (I); Myxoderma, Schmidle (n. gen. in Schmidle, '02 в, p. 246) (I).

VII. Rivulariaceae:-Leptochaete, Borzi (I); Calothrix, C. A. Agardh (incl. Lophopodium, Kütz.) (I8); Dichothrix, Zanardini (6); Rivularia (Roth), C. A. Agardh (incl. Gloeotrichia, J. Ag.) (9).

VIII. Camptotrichaceae :-Camptothrix, W. and G. S. West (n. gen. in West and West, '97 A, p. 269).

This list needs little further comment, since it shows the very large number of species and genera already recorded, and there is no doubt that their number will still be very considerably added to. Many of the species have been recorded from a large number of different localities, whilst in others the range at present appears to be restricted. Attention may also be particularly drawn to the great part played by Scytonema- 
taceae and Stigonemataceae (especially Scytonema, Tolypothrix, Hapalosiphon, and Stigonema), and to the large number of genera of Oscillatoriaceae represented.

\section{The Systematic Composition of the Green Algal Element in the Freshwaters of the Tropics.}

There are certain marked peculiarities of the green algal element as found in tropical freshwaters, which are very manifest in Ceylon, and, judging by the data obtainable from existing floras, equally so in other parts of the tropics. Some of them are so striking that it is astonishing that there has been no previous comment upon them. Although the excess of Cyanophyceae is much the most prominent feature, the peculiar composition of the green algal flora supplements the particular stamp which the former already give tropical freshwater vegetation. The more important features presented by the green element are as follows :-

(a) The relative scarcity of Cladophora and Rhizoclonium, and the consequent scarcity of a number of characteristic epiphytes, which in our waters find one of their main substrata on these filamentous forms (e.g. Cocconeis Placentula, Synedra splendens).

(b) The replacement of these two genera by Pithophora.

(c) The great scarcity of Vaucheria (both aquatic and terrestrial species) and Botrydium.

(d) The relative scarcity of Ulotrichales and Confervales.

(e) The important part played by the genus Spirogyra combined with the relative scarcity of other Zygnemaceae, and the special systematic composition of the Spirogyra-element.

$(f)$ The relative abundance of filamentous Desmids.

$(\mathrm{g})$ The relative scarcity of broad species of Oedogonium (cf. above, p. 246).

These features have been dealt with briefly elsewhere ${ }^{1}$, and a number of explanations to account for them are there suggested. It was, however, not possible to give full data in support of these suggestions, and I propose to do that here.

(i) The Freshwater Cladophoraceae of the Tropics.

Every algologist knows how commonly Cladophora or Rhizoclonium are to be met with in temperate freshwaters, and although no doubt in our parts conditions are often unfavourable for their development in certain waters, no considerable area can be surveyed without finding them well represented in the aquatic vegetation. In Ceylon matters are very different, and one can search for a long time before finding freshwater

\footnotetext{
${ }^{1}$ Fritsch, Proc. Roy. Soc., Ser. B, vol. 1xxix, I907.
} 
representatives of these two genera. Although my collections are very extensive, and were made in many parts of the island, I met with very few occurrences of these Cladophoraceae. The most important habitats were two wells, which were examined; one near the streamlet at Matale, the other at Ambalangodda. The Cladophora in the former case was found in strongly disturbed (i.e. well-aerated) water, and was completely overgrown by Diatoms (mainly Achnanthes, also Gomphonema and Synedra) in a way which I cannot remember to have noticed anywhere else in the freshwaters of Ceylon. Besides these two wells the only other example of the occurrence of Cladophora that I met with was amongst the growth on the stony sides and bottom of the outflow of tank Nuwarawewa. At many points there was a covering of a close black growth forming fingerlike patterns on the bottom, recalling the outline of a thallus of Fucus. This growth was a very short one, and difficult to detach from the rock. It consisted of a number of different forms, amongst which the Cladophora and a Chantransia with monospores were the most important. The Cladophora here was again growing in well-aerated water, and bore a rich growth of epiphytes. As to the other genus, Rhizoclonium, it was only found in the estuaries and lagoons. The observations thus made in Ceylon seemed to indicate that in the tropics both Cladophora and Rhizoclonium can only exist in well-aerated water (flowing or otherwise disturbed water). There are quite a considerable (though relatively to European waters small) number of records of these two genera to be found in tropical algal floras, and we shall do well to enumerate them before drawing further conclusions. They are all derived from the papers enumerated in the bibliography. The records are as follows:-

I. Cladophora amplectens, Welw. MS.-(a) West and West, '97 A, p. 36 (Loanda, on Rhizophora-roots, i. e. a marine form, at times submerged in well-aerated water).

2. Cladophora (Spongomorpha) Beneckei, Möb.-(a) Möbius, '93, p. I 20 (Java, mostly from rivers, also apparently stagnant pools); (b) Schmidle, '00 A, p. $\mathbf{1} 62$ (bogs at Dadar near Bombay); (c) De Wildeman, '00, p. 83 (flowing and stagnant (?) water, Java).

3. Cladophora crispata (Roth), Kütz.-(a) West and West, ' 97 A, p. $3^{6}$ (Loanda, from bottom of a well); (b) West, '04, p. 284 (Porter's Estate, Barbados); (c) Turner, '92, p. I63 (no locality mentioned!); (d) West and West, '96, p. 377 (Mwangadan River, S. of Fuladoga, Central Africa); (e) De Toni, '92, p. 272 (in rushing stream, Lava, Abyssinia); $(f)$ ? Möbius, '88, p. 240 (bathing establishment, Cabo; river and ditches of Coamo).

4. Cladophora diluta, v. Martens.-(a) Martens, '66, p. 20 (rivers, Philippine Islands).

5. Cladophora dubia, Schmidle.-(a) Schmidle, '97 E, p. 26 I (forming incrustations on rocks overflown by spring water, Samoa; water possibly slightly brackish; see also Schmidle, '97 F, p. 285). 
6. Cladophora (Spongomorpha) fluviatilis, Möbius.-(a) Möbius, '93, p. I I 9 (Java, from a river); (b) De Wildeman, '00, p. $\delta_{4}$ (flowing water, Samarang, Java).

7. Cladophora fracta (Kütz.), Brand.-(a) Schmidle, '03 A, p. 86 (littoral region of Lake Nyassa, i.e., well-aerated water); (b) Schmidle, '00 A, p. r6o (no locality mentioned); (c) Möbius, '90, p. 1067 (no locality given); (d) Lemmermann, '05, p. 634 (Oahu, small grotto between Honolulu and Pali ; probably cold water); (e) Lemmermann, '06, p. I60 (same habitat; also ditches between Honolulu and Wakiki).

8. Cladophora glomerata, Kütz.-(a) West and West, '02 в, p. I $3^{2}$ (Ceylon, in running water); (b) ? Möbius, '88, p. 240 (on rocks in river 'Morillos,' near Cayey); (c) Schmidle, '95, p. 294 (var. genuina, Rabh.; Indrapura, West Sumatra).

9. Cladophora incurvata, West and West.-(a) West and West, '02 в, p. I $3^{2}$ (Ceylon, from a pond in the Victoria Park, Colombo ; water artificially aerated?).

ıо. Cladophora javanica, Kütz.-(a) De Wildeman, '00, p. 85 (in the River Brantas, Java).

I I. Cladophora (Spongomorpha) longiarticulata, Nordst.-(a) Nordstedt, '78, p. I9 (in fish-ponds in valleys Nuanu and Paoa in island of Oahu); (b) Lemmermann, '05, p. 634 (sub Clad. Nordstedtii, De Toni; Oahu, marshes in Nuanu and Paoa).

1 2. Cladophora luzoniensis, v. Martens.-(a) Martens, '66, p. 20 (rivers, Philippines).

I3. Cladophora mollis, Ag.-(a) Dickie, '81, p. 124 (near Manaos, \&c.; from river water).

14. Rhizoclonium africanum, Kütz.-(a) Zeller, '76, p. 427 (ad aquaeductum montis Corcovado).

I5. Rhizoclonium biforme, Kütz.-(a) Zanardini, '72, p. I52 (Sarawak-Marop, in rivulis).

16. Rhizoclonium Berggrenianum, Hauck.-(a) West and West, '93, p. 265 (var. dominicense, West and West; Dominica, in hot stream in crater of Grand'Soufrière).

I 7. Rhizoclonium crassipellitum, West and West.-(a) West and West,'97 A, p. 35 (Loanda; a terrestrial species); (b) West, '04, p. 283 (var. robustum, G. S. West; Barbados, on damp ground).

1 8. Rhizoclonium fontinale, Kütz.-(a) Turner, '92, p. I63 (Northern India !) ; (b) Möbius, '88, p. 24I (isolated, on leaves of Naias, from river Quebra-Morillos, Cayey).

19. Rhizoclonium hieroglyphicum, Kütz. ${ }^{-}-(a)$ West, '04, p. 283 (Trinidad, in fountains) ; (b) West, '04, p. 283 (var. Kochianum, Stockm. ; Barbados, in freshwater tank); (c) Borge, '99, p. 7 (Cordoba, Argentine!); (d) Schmidle, '03 A, p. 86

1 According to Schmidle ('97 A), p. 3, Conferva Sandvicensis, Ag. belongs to Rhizoclonium and probably to $R$. hieroglyphicum (Kütz.), Stockm. var. typicum (De Toni), Stockm. With reference to its habitat Schmidle states (loc. cit.): "Ich fand sie in dem von Lauterbach I 889 dort gesammelten Materiale häufig, teils in Wasser von verschiedenen Teichen, teils an überrieselten Felswänden.' The other records for Conferva Sandvicensis are West and West ('97 A), p. 34 (freq. in stagnis puris ad ripas flum. Bero, inter Oedogonium sp.); Nordstedt ('78), p. Is (in Hawaii et in piscinis insulae Oahu); and Lemmermann, '05, p. 632 (Hawaii, Paoa and Nuanu; Oahu). 
(Plankton of a fountain-basin near Langenberg); (e) Schmidle, '00 A, p. I60 (no locality mentioned); $(f)$ Schmidle, '00 A, p. I60 (var. macromeres (Wittr.), Stockm. ; no locality given); $(g)$ Wille, '03, p. 5 , sep. copy (isolated filaments; hot springs, Nhaondue; pools near Mutadzi); (h) Schmidle, '97 E, p. 260 (brackish water, Savaii); (i) Borge, '06, p. 4 (at height of 4,000 metres, i.e. cool water; Laguna, Colorado); $(j)$ Heydrich, '94, p. 27 I (var. Julianum (Menegh.), Rabenh.; rocks, S. Formosa); (k) Schmidle, '95, p. 296 (var. striatum, Schmidle; probably flowing water, West Sumatra); (l) West and West, '99, p. 28I (var. tortuosum, Stockm.; in small stream, Roseau Valley, Dominica); $(m)$ ? Grunow, '67, p. 37 (freshwater, Rio de Janeiro; also var. crassior from Tahiti).

20. Rhizoclonium spongiosum, Dickie.-(a) Dickie, '81, p. I24 (forming spongy masses $\frac{1}{4}$ to $\frac{1}{2}$ inch thick on wet sandstone rocks near Manaos, i.e. a terrestrial form).

N.B.- This list does not absolutely exhaust all the records of freshwater species of these two genera found in the works enumerated in the bibliography at the end of this paper. All those in which a definite habitat was given are included, but a certain number of others, which were extremely vague, have been left out. A number of the records of Cladophora, published prior to Wittrock's monograph of the Pithophoraceae (in Nova Acta Reg. Soc. Sc. Upsala., Ser. 3, 1876), really refer to species of Pithophora (cf. loc. cit,, pp. 2 and 3)-possibly even some of the later ones, although Pithophora is on the whole quite easily distinguished from Cladophora, even in the sterile condition, by its habit and its mode of branching (loc. cit., p. 4).

Where details as to habitat are given, the important feature from the present point of view is indicated by the use of black type.

I think it is scarcely necessary to make much further comment on this list. It shows that in a large number of cases the individuals of these two genera were found in flowing water or in water which was better aerated than the ordinary freshwaters of the tropics are. The remaining cases cannot be taken as a decisive proof to the contrary until such habitats have been fully studied. Moreover, as in the majority of cases there is absolutely no mention of the amount of the Alga, we do not know whether we are dealing with an abundant form or merely with an isolated occurrence. A number of the localities, which do not obviously point to wellaerated water, are very suggestive of artificial aeration (e. g. that inhabited by Messrs. West and West's Cladophora incurvata ${ }^{1}$ ).

It will have been gathered from the preceding remarks that I am attempting to show that Cladophora and Rhizoclonium are relatively so scarce in tropical freshwaters, because the ordinary waters are too poorly aerated to admit of their existence. Owing to their higher temperature tropical waters contain a far smaller amount of the essential gases (oxygen and carbon dioxide) than do those of temperate regions. In

\footnotetext{
1 I unfortunately omitted to visit this locality during my stay in Ceylon.
} 
illustration of this statement we may take the following data from Forel ${ }^{1}$ dealing with the relative amounts of dissolved atmospheric gases (per litre) as found in waters (Lake of Geneva) of different temperatures:-

$\begin{array}{cccc}\text { Temperature } & \mathrm{O} & \mathrm{N} . & \mathrm{CO}_{2} . \\ 5{ }^{\circ} \mathrm{C} . & 7.3 \mathrm{cc} . & \mathrm{I} 3.6 \mathrm{cc} . & 0.6 \mathrm{cc} . \\ 20^{\circ} \mathrm{C} . & 5.7 \mathrm{cc} . & 10.7 \mathrm{cc} . & 0.3 \mathrm{cc} .\end{array}$

The lowest temperature attained by the lowland waters of Ceylon I found to be $25^{\circ} \mathrm{C}$., so that the amount of dissolved oxygen will probably be less than $5 \mathrm{cc}$. Both Cladophora and Rhizoclonium have thick coarse walls, which are not suitable for a ready diffusion of gases from the surrounding water, and even in temperate regions these two genera seem to flourish best in waters which are not absolutely stagnant. Moreover, their period of maximum abundance generally falls into the cold part of the year, and although not completely absent in the summer they are much reduced in quantity. From this point of view, therefore, we need not be surprised to find the two genera in question very scantily represented in tropical freshwaters, and practically confined to such as are in some way or other well aerated. It is of course not impossible that certain species of Cladophora or Rhizoclonium can occasionally frequent stagnant water in the tropics, but up to the present there is no conclusive evidence on this point.

I found the order Cladophoraceae in Ceylon mainly represented by species of Pithophora. They cannot be said to be really common forms, although frequent enough to be a sensible constituent of the algal flora. As regards their habitat, they appear to favour mainly the smaller pieces of water, and were not met with in the larger tanks. Reference to the literature shows a remarkably small number of records of species of this genus ${ }^{2}$, which does not at all tally with my observations in Ceylon. Can it be that some of the records of Cladophora above enumerated really concern species of Pithophora? I do not think it very likely, but it is well to keep the possibility in view. It does not, however, seem at all probable that Ceylon is exceptional in the relative abundance of Pithophora as compared with the other Cladophoraceae, and we must await a careful investigation of the algal flora in some other part of the tropics before this point can be absolutely settled. In its relatively thin walls Pithophora certainly seems better suited than the other Cladophoraceae for life in tropical waters, and in Ceylon I frequently observed it in water which

1 Allgemeine Biologie eines Siisswassersees, in Zacharias, Die Tier- und Pflanzenwelt des Süsswassers. Leipzig, I89ז, p. I5.

2. The more important species are: Pithophora aequalis, Wittr.; P. affinis, Nordst.; P. clavifera, Schmidle; $P$. Cleveana, Wittr.; $P$. oedogonia (Mont.), Wittr.; $P$. pachyderma, Schmidle; $P$. poiymorpha, Wittr.; $P$. radians, W. and G. S. West; $P$. Reineckei, Schmidle; $P$. Roettleri (Roth.), Wittr.; P. sumatrana (Mart.), Wittr.; P. variabile, Schmidle. 
was absolutely stagnant ${ }^{1}$. In addition to its thinner walls and often narrower filaments, however, Pithophora differs in another respect from the other members of the Order. It is capable of forming specialized resting-spores (akinetes), which may be a feature of great advantage to it in view of the frequency of rather sudden desiccation in tropical waters, especially in the smaller ones, in which Pithophora was almost alone observed in Ceylon. It is just possible that this may be a second factor contributing towards the scarcity of Cladophora and Rhizoclonium, and that their means of existence during times of exposure and desiccation may not be suited to the exigencies of the tropics. This factor is, however, certainly in no way as important as the aeration of the water.

Pithophora is certainly a prevalently tropical genus-in fact, all the European records are subject to the suspicion of the forms found there being introduced ${ }^{2}$.

With the great scarcity of Cladophora and Rhizoclonium in tropical freshwaters goes hand in hand the lack of one of the most important substrata for aquatic algal epiphytes. Every one is probably familiar with the dense covering of characteristic Diatoms (Cocconeis, Gomphonema, Synedra splendens, \&c.) found in temperate regions on the filaments of the two genera in question, often completely enshrouding them in an heterogeneous brown mass. Scarcely any other filamentous Alga (saving perhaps Vaucheria, which is also very scarce in tropical waters, cf. below) approaches the Cladophoraceae in this respect, and in tropical waters, where these genera are not represented, epiphytic algal growth is rarely at all well developed. There are, however, other reasons to account for this. A large number of the Diatoms generally seem to prefer cold to warm water, and with us mostly attain their maximum in the cold winter months, and steadily decrease in amount as the water becomes warmer in spring. There are, however, also a number of Diatoms which exist in great numbers in much warmer waters, as is shown by the numerous records of their occurrence in hot springs. These latter, besides including cosmopolitan species, consist mainly of a few probably specialized forms (filamentous Diatoms seem to be predominant). In waters of intermediate temperature, such as are afforded by those of the tropics, the conditions seem unfavourable both for the colder forms and for the hot-spring forms, and the Diatom-flora is generally poorly developed. In Ceylon I only met with Diatoms in striking abundance in river-waters, as epiphytes on Cladophoraceae in wells, and in the hot springs (Kannia near Trincomalee).

1 That Pithophora, however, also has a taste for aerated water is shown by the fact that it was found commonly in the water of wells examined in Ceylon.

${ }^{2}$ There are no data as yet forthcoming as to the distribution of Schmidle's new genus Chactonella with C. Goetzei (Schmidle, '02 B, p. 253). Further observation may show it not sufficiently distinct to warrant generic separation. The habitat is in accord with the general remarks made above ('Pfiitze in der Nähe der Brandung'). 
In minor numbers they are generally present in every collection, although certain types of waters are practically destitute of them.

From what I have seen in Ceylon it seems as though the epiphytic Diatoms of tropical waters were not in general quite the same as those found in our parts of the world. The species of Cocconeis in particular are very rare, whilst Achnanthes seems to play a very much more important part than with us. Most of the tropical floras, however, give us little or no information about Diatoms ${ }^{1}$, and I prefer, therefore, to omit further speculation on this subject until more data are available for general verification. In the case of abundant occurrence of tropical freshwater Diatoms it is also of course of the utmost importance to have full descriptions of the habitats. It seems as though the small amount of dissolved gases in the water may again be the governing factor in determining the scarcity of this group in stagnant tropical waters.

\section{(ii) The Freshwater and Terrestrial Siphoneae of THE TROPICS.}

The genus Vaucheria is quite evidently very poorly represented in the tropics. In the case of Ceylon I have not as yet found a single example of its occurrence in the lowlands, although (in the course of a six days' stay only) in the uplands, at a height of 6,000 feet and more, both aquatic and terrestrial forms were met with. The literature is equally poor in records of this genus; the following are extracted from the papers in the bibliography:-

I. Vaucheria geminata (Vauch.), DC.-(a) Hieronymus, '95, p. 23 (in ditches, \&c.).

2. Vaucheria humicola, Lagerh.-(a) Lagerheim, '90, p. I4 (in terra humida horti botanici Quitensis ${ }^{2}$ ).

3. Vaucheria repens (Hass.), Klebs. $-(a)$ Schmidle, '02 A, p. 64 (forma nasuta, Schmidle; on damp stones in streamlet Njasoso and on damp soil on the banks; Africa).

4. Vaucheria sessilis (Vauch.), DC.-(a) West and West, '97 A, p. 235 (Golungo Alto $^{2}$, Africa. In fossis exsiccatis adhuc humidis in Varzea pone dom. Isidni; covers in Aug. and Sept. all the half-dried-up ditches of the plain): (b) West and West, ' 97 A, p. 235 (var. monogyna, W. and G. S. West; Golungo Alto ${ }^{2}$, Africa. Ad margines stagnorum rivi Cuango, Aug. I 857); (c) Zeller, '73, p. I 86 (var. cespitosa Ag.; Pegu, Yoma centralis, Khayeng-mathay-choung, Burma. Var. repens, Hass., ibidem, in limo siccescente); (d) Zeller, '76, p. 427 (var. subarticulata, Zeller; no locality).

Sterile species of Vaucheria are recorded by $(a)$ Dickie, '81, p. I 25 (on moist earth, Porto Salvo, Rio Purus); (b) Schmidle, '03 A, p. 86 (Plankton of Nyassa, near Langenburg!); (c) De Toni, '92, p. 272 (in rivulis, inter Gheleb et Maigerghebit); (d) Turner, '92, p. I 55 (in fragmentary condition only; Bengal, Central India!);

${ }^{1}$ Cf., however, De Wildeman ('00), West and West ('02 B), Lemmermann ('05 and '06), Gutwinski and Chmielewski ('06), Dickie ('81).

${ }^{2}$ These localities are situated at a high altitude. 
(e) West, '04, p. 284 (Roy. Bot. Gards., St. Anns, Trinidad!); $(f)$ Hieronymus, '95, p. 23 (in a drain and small waterfall); $(g)$ Martelli, '86, p. I 5 I (Sciotel, Alle falde della Zedamba).

These are all the records there are, and while they serve to show that Vaucheria does occur in the tropics, they point to conditions being on the whole unfavourable to it. An examination of the records just enumerated also shows that in the majority of cases the Vaucheria found was a terrestrial form (often growing at a higher altitude), and not aquatic. This seems to indicate that the water is particularly unsuitable for these forms in the tropics, and, bearing in mind the broad filaments generally found in this Alga, one inclines to the assumption that the same factor is responsible for the great scarcity of aquatic Vaucheria, as was suggested as the probable cause for the rarity of tropical freshwater Cladophoras and Rhizocloniums, viz. the small amount of dissolved oxygen in the water. This view receives some support from the fact that marine species of Vaucheria (i. e. forms growing in well-aerated water) are apparently not at all uncommon in the tropics (cf., for instance, De Wildeman, '00, p. 89). There are, however, other special features in the genus Vaucheria, which may be an unsuitable equipment for tropical life. The assimilatory process is decidedly different to that of the majority of green Algae, ${ }^{1}$ the reserve-product being oil and the chloroplasts being yellowish and devoid of pyrenoids. It is possible that in some way or other assimilation of this type may not go on well amid tropical conditions (cf. below)-perhaps it is more successful on the land than in the water.

Although Ceylon affords many likely localities for Botrydium I did not find it, and other collectors have been almost equally unsuccessful. There are only three records, viz.:-B. argillaceum, Wallroth (Martens, '70, p. 298 ; 'in praeruptis viarum argillosis, in fossis limosis ad Ypanema, Prov. S. Pauli, tempore pluvio') ; B. gramulatum (L.), Grev. (Lagerheim, '90, p. 7 ; 'En los muros de las calles exteriores de Quito') ; and B. granulatum (L.), Grev. var. aequinoctiale, W. and G. S. West (West and West, '97 A, p. 235 ; 'Loanda. Non infrequens in territor. Loandensis terris humidis argillaceoarenosis, latas plagas imo urbis ipsius plateas, etc., obtegens; mox post pluvias copiosas nascens, citoque tempore sicco disparens'). Botrydium is, of course, a form which is fairly readily overlooked, and my main object is to draw attention to the few records. As far as the assimilatory process is concerned Botrydium is, however, in the same position as Vaucheria.

\section{(iii) The Confervales in the Tropics.}

In dealing with Vaucheria and Botrydium one naturally also turns one's attention to the Confervales, a group to which the latter genus is now generally referred, whilst the inclusion of Vaucheria in the Confervales is

${ }^{1}$ Cf. Oltmanns, Morphologie und Biologie der Algen. Zweiter Band. Jena, 1905, p. I47. 
also advocated by some. In looking over the records of tropical freshwater Confervales one comes to the conclusion that this group is also one which plays no great part in the tropics, though certainly represented by a number of forms. The records are as follows:-

I. Characiopsis ellipsoidea, G. S. West.-(a) West, '04, p. 288 (near Bridgetown, Barbados ; epiphytic on Chara, sp.).

2. Conferva Ansonii, Agardh.-(a) Schmidle, '00 D, p. 10 (Marianne Islands, in a spring).

3. Conferva bombycina, Ag.-(a) West and West, '93, p. 265 (f. minor, Wille; in cold, warm, and hot streams, crater of Grand'-Soufrière, Dominica); (b) West and West, ' 97 A, p. 34 (f. minor, Wille ; Pungo Andongo; ad ramulos Podostemacearum in rivulis, Casalalé); (c) De Toni, '92, p. 27 I (in alveo flumin. Anseba, pr. Arbasciko); (d) Möbius, '95, p. 175 (in a small lake, 2,300 metres altitude, Itajahy); (e) Lemmermann, '05, p. 63 I (var. minor, Wille; Oahu, Maluhia!); $(f)$ Prain, '05, p. 329 (River Hughli, near Kidderpore; Botanic Garden, Shibpur, in ponds); $(g)$ Zanardini, '72, p. I 5 I (Sarawak, in rivulis montis Mattang); (h) Lagerheim, '90, p. 3 (wet soil in botanic gardens, Quito).

4. Conferva fontinalis, Berk.-(a) Turner, '92, p. I62 (Northern India!); (b) Zanardini, '72, p. I5 I (var. ochracea; Sarawak-Marop, in rivulis).

5. Conferva funicularis, Agardh.-(a) Schmidle, 00 D, p. Io (Mariana Islands, in the river Agana).

6. Conferva Glaziovii, Zeller.-(a) Zeller, '76, p. 426 (in Vaucheria sessili parasitica).

7. Conferva sandvicensis, Ag.-See footnote on p. 250.

8. Conferva tenerrima, Kütz.-(a) Turner, '92, p. 163 (Northern India!); (b) Schmidle, '02 B, p. $25^{2}$ (Masote, in river Siwa, but in stagnant water).

9. Ophiocytium Arbuscula, A. Br.-(a) Lagerheim, '90, p. I3; (b) Bohlin, '97, p. 30 (Paraguay!).

ı. Ophiocytium biapiculatum, Hieron.-(a) Schmidle, '03 A, p. 83 (quiet bay of Mbasi-river near its point of inflow into Lake Nyassa); (b) Hieronymus, '95, p. 22 (marshes).

I I. Ophiocytium bicuspidatum, Lemm.-(a) West and West, '02 A, p. I6o (in muddy ricefield).

12. Ophiocytium capitatum, Wolle-(a) Lagerheim, '93, p. I59 (with Utricularia inflexa, Forsk.); (b) West and West, '02 в, p. I 30 (var. longispinum, Lemmermann; running water, Royal Botanic Gardens, Peradeniya).

13. Ophiocytium cochleare, Näg.-(a) West and West, '95, p. 82 (Madagascar); (b) Borge, '99, p. 9 (Argentina, Cordoba!); (c) Turner, '92, p. I 54 (no locality); (d) De Wildeman, '97, p. 79 (Dutch Indies); (e) Wille, '84, p. I I (Caldas!); $(f)$ Schmidle, '03 4 , p. 83 (ditch near Langenburg); $(g)$ Schmidle, '95, p. 296 (no locality); (h) De Wildeman, '00, p. Io6 (ditches, marshes); (i) Nordstedt, '80, p. 12 (in Utricularia Eckloni); $(j)$ Gutwinski, '02 A, p. 577 (var. bicuspidatum, Borge); (k) Hieronymus, '95, p. 22 (marshes); (l) Lagerheim, '90, p. I3 (en los pantanos en S. Rita); (m) Bohlin, '97, p. 29 (Paraguay, Matto Grosso ; also vars. bicuspidatum and longispinum). 
14. Ophiocytium cuspidatum (Bail.), Rabh.-(a) Borge, '99, p. 9 (Guiana!).

15. Ophiocytium gracilipes, A. Br.-(a) Lemmermann, '05, p. 63I (Oahu, small grotto between Honolulu and Pali); (b) Gutwinski, '02 A, p. 577 ; (c) Lemmermann, '06, p. I60 (same as $a$ ); (d) Bohlin, '97, p. 30 (Matto Grosso!).

I6. Ophiocytium majus, Näg.-(a) Turner, '92, p. I54 (Northern India!) ; (b) West and West, '97 A, p. 236 (Pungo Andongo; in stagnis prope Anbilla, Condo); (c) Lagerheim, '93, p. I 59 (also var. gordianum, Istv. ; with Utricularia inflexa, Forsk.); (d) Borge, '96, p. 7 (Johnstone River, Queensland).

17. Ophiocytium parvulum, A. Br.-(a) West and West, '02 A, p. I6 I (in muddy rice-field); (b) West and West, '97 A, p. 236 (Pungo Andongo; in stagnis prope Anbilla, Condo); (c) West and West, '02 в, p. I3 I (stream, Victoria Park, Colombo); (d) Schmidle, '95, p. 296 (no locality); (e) Schmidle, '02 A, p. 64 (Abo River); $(f)$ Lagerheim, '90, p. I3 (en los pantanos en S. Rita); $(g)$ Bohlin, '97, p. 29 (Paraguay, Matto Grosso!).

The most important form, as far as number of species and records go, is thus Ophiocytium. Conferva (especially if we follow Schmidle and exclude $C$. sandvicensis, Ag.) is not very well represented, and a perusal of the records of this genus shows that, like Rhizoclonium and Cladophora, it favours well-aerated water (rivers and waters at a high altitude). In Ceylon I have only met with occasional filaments of Conferva, although future more thorough investigation is sure to disclose a number of the unicellular forms ; certainly, however, none of them is abundant. One cannot help thinking of the peculiar type of assimilation as another explanation of the scarcity of Conferva (i. e. in addition to its apparent desire for well-aerated water). As in the case of Vaucheria and Botrydium, however, this point must remain open until we have far more precise data as to the kind of tropical habitats frequented by these forms.

\section{(iv) The Ulotrichales in the Tropics.}

It is not quite apparent from existing data whether the Ulotrichales are really rarer in the tropics than in temperate waters. I am tempted to such a conclusion by my observations in Ceylon, where they certainly, as far as the lowland waters are concerned, are relatively scarce. Messrs. W. and G. S. West, in their work on the freshwater Algae of Ceylon (West and West, '02 B, p. I 24), also comment on this fact ; they say: 'Very few Algae were observed belonging to the families Confervaceae and Ulotrichaceae ; this we are unable to account for, as many of the collections were from suitable localities for these plants.' It again does not seem likely that Ceylon is exceptional, although possibly poorer in these forms than other parts of the tropics. As far as existing data go, there is nothing in the records of tropical Ulotrichales to point to their being bound to special conditions, and I think, therefore, that it will be sufficient to enumerate the species of this group so far recorded from tropical freshwaters. The 
different genera are arranged according to Blackman and Tansley's 'Revision' 1 :-

\section{Ulotrichaceae :-}

I. Ulothrix minutula, Kütz. (Nordstedt, '78, p. 22 ; Lemmermann, '05, p. 632); $U$. oscillarina, Kütz. (Wille, '84, p. 25 ; ? Dickie, '81, p. 124); U. pectinalis, Kütz. (Prain, '05, p. 329); U. subtilis, Kütz. (Schmidle, '03 A, p. 85 ; Zeller, '73, p. I89; Lemmermann, '05, p. 632); U. subtilis, Kütz., var. variabilis (Kütz.), Kirchn. (West, '04, p. 282 ; West and West, '96, p. 377); U. tenuis, Kütz. (Möbius, '95, p. I 74); U. tenerrima, Kütz. (Turner, '92, p. I62); U. zonata, Kütz. (Turner, '92, p. I62).

I $a$. Hormiscia ${ }^{2}$ aequalis (Kütz.), Rabenh. (Schmidle, '02 A, p. 62; Schmidle, '00 D, p. 9); H. oscillarina (Kütz.), De Toni (De Toni, '92, p. 27 I ; Schmidle, '02 A, p. 62);H. rigidula, Kütz. (Schmidle, '00 A, p. 160 ); H. subtilis (Kütz.), De Toni (West and West, '97 A, p. 33; Nordstedt, '97, p. I3 I) ; H. subtilis, var. stagnorum, Kirchn. (Schmidle, '00 A, p. I60); H. subtilis, var. tenerrima, Kirchn. (West and West, '02 в, p. 129 ; Schmidle, '97 E, p. $\left.25^{8}\right)$; H. subtilis, var. thermarum (Wartm.), Rabenh. (Schmidle, '02 A, p. 62); H. subtilis, var. variabilis, Kirchn. (Schmidle, '00 A, p. 160 ; West and West, '97 A, p. 33); H. zonata, Aresch. (Möbius, '93, p. І I8; De Wildeman, '00, p. 59).

2. Hormidium, see p. 240.

3. Uronema confervicolum, Lagerh. (West, '04, p. 283); U. confervicolum, Lag. var. javanicum, Möb. (Möbius, '93, p. I I 8 ; De Wildeman, '00, p. $5^{8}$ ).

\section{Prasiolaceae:-}

4. Schizogonium tenuissimum, Zeller (Zeller, '73, p. I89).

III. Microsporaceae:-

5. Microspora abbreviata (Rabh.), Lag. (Schmidle, '03 A, p. 85 ; West and West, '02 A, p. I60; West and West, '97 A, p. 34 ; Schmidle, '02 A, p. 62 ; West and West, '99, p. 280) ; M. amoena (Kütz.), Rabenh. (West and West, '97 A, p. 34 ; Schmidle, '02 A, p. 62); M. De Toniana, Lagerh. (Lagerheim, '93, p. I57); M. floccosa, Thur. (? Möbius, '93, p. I 19; West and West, '02 в, p. 130; De Wildeman, '00, p. 63) ; M. fontinalis (Berk.), De Toni (West and West, '97 A, p. 34); M. Löfgrenii, Nordst. (West and West,'97 A, p. 34); M. pachyderma (Wille), Lagerh. (West and West, '99, p. 280; Borge, '96, p. 6); M. stagnorum (Kütz.), Lagerh. (Lagerheim, '90, p. I2); M. Willeana, Lagerh., var. abyssinica, De Toni (De Toni, '92, p. 271); M. Wittrockii (Wille), Lagerh. (West and West, '97 A, p. 34 ; Lagerheim, '90, p. I2).

\section{Chaetophoraceae:-}

6. Stigeoclonium amoenum, Kütz. (Nordstedt, '97, p. 132); S. falklandicum, Kütz. (Nordstedt, '78, p. 22 ; Lemmermann, '05, p. 632); S. macrocladium (Nordst.), Schmidle, var. tomentosum, Schmidle (Schmidle, '00 A, p r62); $S$. plumosum, Kütz. (Dickie, '81, p. I23); S. protensum, Kütz. (? Turner, '92, p. I63);

1 New Phytologist, vol. i, I902.

${ }_{2}^{2}$ I have thought it better to place the records under the two genera Ulothrix and Hormiscia as they are found in the literature, although a number of the species are of course synonymous. 
S. Rangoonicum, Zeller (Zeller, '73, p. 19I); S. spicatum, Schmidle (De Wildeman, '97, p. 73; De Wildeman, '00, p. 6r ; Schmidle, '95, p. 294); S. tenue, Rabh. (Schmidle, '00 A, p. 160 ; Schmidle, '01 A, p. 46 ; Zeller, '73, p. 19г ; Möbius, '92, p. 24); S. thermale, A. Br. (Schmidle, '01 A, p. 46); S. uniforme (Ag.), Rabenh. (Hieronymus, '95, p. 23).

7. Chaetophora elegans (Roth), Ag. (Lagerheim, '90, p. I I); C. pisiformis, Ag. (Zeller, '73, p. I91) ; C. radians, Kütz. (Zeller, '73, p. 191); C. stricta, Zeller (Zeller, '73, p. I9r); C. tuberculosa (Roth), Hook. (De Wildeman, '97, p. 73 ; De Wildeman, '00, p. 6r ; Zeller, '73, p. 19I).

8. Draparnaldia glomerata (Vauch.), Ag. (Lagerheim, '90, p. II); D. macroclada, Nordst. (Nordstedt, '78, p. 22 ; Lemmermann, '05, p. 632).

9. Aphanochaete Braunii (Näg.) (De Wildeman, '97, p. 72 ; De Wildeman, '00, p. 59); A. crassisetum (W. and G. S. West) (West and West, '02 в, p. г 30 ); A. pilosissima, Schmidle (West and West, '02 в, p. 125); A. polychaete (Hansg.), Fritsch (Lagerheim, '93, p. 157 ); A. repens, A. Br. (West and West, '02 $\mathrm{A}$, p. ${ }_{5} 5^{8}$; Nordstedt, '78, p. 23 ; Borge, '96, p. 6 ; Lemmermann, '05, p. $63_{2}^{2}$; Lemmermann, '06, p. I60; Lagerheim, '90, pp. 3 and II).

ı. Endoderma immane, Schmidle (Schmidle, '00 A, p. I 67 ; Schmidle, ${ }^{\prime} 00$ в, p. I 7) ; E. Pithophorae, G. S. West (West, '04, p. 283); E. polymorpha, G. S. West (West, '04, p. 283); E. Reineckei, Schmidle (Schmidle, '97 E, p. 259; West and West, '02 в, p. I 29).

I I. Psephotaxus lamellosus, W. and G. S. West (West and West, '97 A, p. 33).

12. Chaetopeltis minor, Möb. (Schmidle, '01 A, p. 46).

\section{Chaetosphaeridiaceae:-}

I3. Chaetosphaeridium globosum (Nordst.), Klebahn (Nordstedt, '78, p. 23 ; Wille, '84, p. 25 ; Lemmermann, '05, p. 633); C. Pringsheimii, Klebahn (Borge, '99, p. 7 ; De Wildeman, '97, p. 73 ; De Wildeman, '00, p. 60; Schmidle, '01 A, p. 46).

\section{Coleochaetaceae :-}

14. Coleochaete irregularis, Pringsh. (West and West, '95, p. 42; Schmidle, '01 A, p. 46; Borge, '96, p. 3; Nordstedt, '78, p. 23 ; Lemmermann, '05, p. ${ }_{333}$ ) ; C. javanica, De Wildeman (De Wildeman, '97, p. 52 ; De Wildeman, '00, p. 48); C. orbicularis, Pringsh. (Schmidle, '00 A, p. r60; Nordstedt, '78, p. 23; Lemmermann, '05, p. 633; Gutwinski and Chmielewski, '06, p. 2); C. scutata, Bréb. (Turner, '92, p. I64; ? Wille, '84, p. 26 ; Schmidle, '00 A, p. г60; West and West, '02 в, p. 125; Borge, '96, p. 3; Dickie, '81, p. г23); C. soluta, Pringsh. (Lagerheim, '93, p. I55; West and West, '02 в, p. 125).

IX. Chrodepideae (see pp. 242, 243).

The genera best represented are thus Microspora, Stigeoclonium, Ulothrix, and, to a less extent, Aphanochaete ; Coleochaete is evidently quite a common form, and I also met with it fairly frequently in Ceylon. It is interesting that there is practically no record of a Prasiola from the tropics. This genus is, however, a terrestrial form, and as such is probably excluded by the same factors as oppose the development of subaerial green forms 
generally (p. 239). Draparnaldia has as yet only been recorded from the Sandwich Islands and Ecuador; it was not observed in Ceylon.

Although a considerable number of different species and genera of Ulotrichales are thus known to occur in the tropics, the number of actual records is not very great, and I am inclined to think that this group does after all take rather a back place in these regions. Possibly this may again be a result of the difficulties of respiration in the tropics, although there is nothing to show that these forms favour specially well-aerated tropical waters. Some species of Ulothrix, even in our parts of the world, are known to flourish best in flowing water, and it seems very possible that forms, which can get on satisfactorily in stagnant temperate waters, may be unsuccessful in similar tropical habitats. After all, we know as good as nothing at present as to the influence of the amount of dissolved oxygen in the water on the various freshwater algal genera.

\section{(v) The Zygnemaceae in the Tropics.}

Probably no feature of the freshwater algal flora of the tropics has played such a part in producing the universal impression of similarity with that of temperate regions as the excessive abundance of Spirogyra. This genus is indeed even more abundant than it is with us, and yet careful examination of the available data shows that the tropical Spirogyras have certain characteristic features, which are sufficiently striking. Spirogyra is of course an essentially stagnant-water form, and this, I think, is one reason for its immense success in the tropics. As pointed out above (p. 246) Spirogyra and Pithophora (together with a certain number of species of Oedogonium) are the only forms with really broad filaments found in the ordinary tropical freshwaters, and I am inclined to associate this with the evident small demand for aerated water made by Spirogyra. Moreover, the narrower species of this genus are even rather scarce in the tropics, and the broad ones are dominant (see the measurements given in the enumeration below). In relation to this point we have also to notice that species of Spirogyra with a single spiral in their cells are scarce (twenty records), and that the majority of forms have two, three, or more such chloroplasts (sixty-two records). Lastly, only five (viz. S. inflata, S. quadrata, S. temiissima, S. Grevilleana, and S. insignis) of the forms hitherto recorded (six records) have infolded transverse walls, the latter almost invariably being simple. ${ }^{1}$ The same observations were made on the abundant material of Spirogyra collected in Ceylon; broad forms with many spirals were preponderant, and no case of infolded end-walls has been met with up to the present.

1 Amongst the Spirogyras enumerated by De Toni ('89, p. 743 et seq.) there are thirty species with a single chloroplast and forty-three with two or more in their cells; amongst the species known from the tropics there are nine with a single spiral, and twenty-nine with two or more spirals. The difference in number is obvious. De Toni has twenty-two species with infolded walls as compared with fifty-one with simple end-walls. In the tropical records the relation is $5: 33$. 
In the following enumeration of tropical Spirogyras ${ }^{1}$, the species are arranged according to the number of chloroplasts in the cells in order to bring out the above point. The average width of the filaments in each species is added in brackets :-

(i) Cells with a single spiral :-

I. Sp. $\operatorname{arcta}(\mathrm{Ag}),. \mathrm{Kütz} .(33-36 \mu)$ :-West and West, '96, p. 377 .

2. S. cateniformis (Hass.), Kütz. $(26-27 \cdot 5 \mu)$ :-Borge, '03, p. 280.

3. S. condensata (Vauch.), Kütz. $(48-62 \mu)$ :-? Möbius, '90, p. 1069 .

4. S. Goetzei, Schmidle $(22-24 \mu)$ :-Schmidle, '02 в, p. 25 I.

5. S. gracilis, Kütz. $(\mathbf{1} 7 \cdot 5-19 \mu):-W e s t$ and West, '02 A, p. 162 ; Lagerheim, '93, p. 162 (var. $\beta$ abyssinica, Lagerh., 1 10 diam.).

6. S. inflata (Vauch.), Rabh. (I8-19.5 $\mu$ ):-Borge, '03, p. 279.

7. S. longata, Kütz. $(24-27 \mu)$ :-Schmidle, '00 A, p. х6г ; Schmidle, '02 в, p. 25 I ; ? Dickie, '81, p. 125 ; Zeller, '73, p. 185 ; Prain, '05, p. 328 (f. elongata, Kütz.) ; Lagerheim, '90, p. 7 (f. elongata, Kütz.) ; Lagerheim, '90, p. г 5 ; Möbius, '89, p. 3 I 4 (f. elongala).

8. S. quinina, Kütz. $(25 \cdot 5-43 \mu)$ :-Zeller, '73, p. 185 ; Borge, '06, p. 6 (sub $S$. porticalis (Müll.), Cleve).

9. S. tenuissima (Hass.), Kütz. $(8 \mu)$ :-Lagerheim, '90, p. 7 (var. plena, Lagerh.).

(ii) Cells with two or three spirals:-

I. S. adnala, Kütz. ${ }^{2}(40-45 \mu)$ :-Zeller, ' 73 , p. 185 . (2 spirals!)

2. S. angolensis, Welw. MS. $(49-63 \mu)$ :-West and West, '97 A, p. 4I. (2, rarely 3 spirals!)

3. S. decimina, Kütz. $(32-5 \circ \mu)$ :-West and West, '95, p. $4^{2}$; West and West, '02 А, p. г6г ; West and West, '02 в, p. г33; Zeller, '73, p. 185; Zanardini, '72, p. I $5^{2}$. (2, rarely 3 spirals!)

4. S. dubia, Kütz. (43-50 $\mu$ ):-West and West, '96, p. 378 ; Dickie, '81, p. 125 (var. longiarticulata). (2 or 3 spirals !) spirals !)

5. S. Grevilleana (Hass.), Kütz. $(20-33 \mu)$ :-Borge, '03, p. 280 . (I or 2

6. S. irregularis, Näg. ${ }^{2}\left(3^{2-36} \mu\right)$ :-Zeller, ${ }^{3} 73$, p. 185 . (2 or 3 spirals!)

7. S. quadrata (Hass.), Petit $(27-33 \mu)$ :-Schmidle, '02 B, p. 25 I ; Lagerheim, '90, p. I 5 . (I or 2 spirals!)

8. S. rupestris, Schmidle $(33 \mu)$ :-Schmidle, '00 A, p. I 70 ; Schmidle, '00 в, p. 18. (2 or 3 spirals!)

9. S. Schmidtii, W. and G. S. West $\left(3 \mathrm{I}-35^{\mu}\right)$ :-West and West, '02 A, p. I6 I. ( 2 or 3 spirals!)

10. S. Welwitschii, W. and G. S. West $\left(65^{-75 \mu)}\right.$ :-West and West, ' 97 A, p. 4 I. (2, rarely 3 spirals!)

(iii) Cells with three or often a larger number of spirals :-

I. S. crassa, Kütz. (г $20-\mathbf{1} 5 \circ \mu)$ :-Zeller, '73, p. I 85 ; Gutwinski, '02 A, p. $57^{8}$ (var. maxima (Hass.), Hansg.) ; Prain, '05, p. 329 (sub S. Heeriana, Näg.).

1 Undetermined sterile species are not taken into account.

2 A certain amount of doubt attaches to these determinations. 
2. S. cylindrospora, W. and G. S. West $(70-77 \mu)$ :-West and West, '97 1, p. 42.

3. S. Füllebornei, Schmidle $(40-42 \mu)$ :-Schmidle, '03 A, p. 76.

4. S. Holstii, Hieron. $\left(55^{-6} 5 \mu\right)$ :-Hieronymus, '95, p. 2 I.

5. S. insignis (Hass.), Kütz. (39-42 $\mu$ ):-Möbius, '89, p. $3^{\text {I } 4}$.

6. S. jugalis, Kütz. $(72-98 \mu):-Z$ Zeller, '73, p. 185 .

7. S. lineata, Suring. (5०-65 $\mu$ ):-Henriques, ' 86 , p. 2 I8 (f. gracilior).

8. S. majuscula, Kütz. $(54-62 \mu)$ :-Zeller, '73, p. I 85 ; De Wildeman, '97, p. 84 (var. minor, Wittr. et Nordst.); De Wildeman, '00, p. I I 6 (var. minor, Wittr. et Nordst.).

9. S. Malmeana, Hirn ( $\left.7^{6-91} \mu\right)$ :-Schmidle, '01 A, p. 46 (var. minor?) ; Borge, '03, p. 28 I.

1о. S. maxima, Wittr. (1о4-1 I7 7 ):-Borge, '99, p. ro; Borge, '03, p. 28 I.

I I. S. neglecta, Kütz. $(53-65 \mu)$ :-West and West, '02 A, p. I6 г ; West and West, '02 в, p. I33; West and West, '96, p. 378 (var. ternata (Ripart)); West and West, '97 A, p. 4 I (var. ternata); West and West, '99, p. 28 r (var. ternata).

I 2. S. nitida (Dillw.), Link. (6o-78 4 ):-? Möbius, '93, p. I23; Schmidle, '95, p. 298 ; De Wildeman, '00, p. I I 4 ; ? Möbius, '90, p. ı०68; Prain, '05, p. 328 ; Zeller, '73, p. I85; Martens, '66, p. 2 I ; Askenasy, '89 (sub S.princeps (Vauch.), Cleve).

13. S. pallida, Dickie ? $(3 \circ \mu)$ :-Dickie, '80, p. 28 I (see also Hieronymus, '95, p. 2 I).

I4. S. paraguayensis, Borge $(4 \mathrm{I}-45 \mu)$ :-Borge, '03, p. 280.

I5. S. Reinhardii, Chmiel. ( I 88-I I $7 \mu$ ):-Borge, '03, p. 28 I.

16. S. rivularis, Rabh. $\left(3^{6-40 \mu):-S c h m i d l e, ~ ' 02 ~ A, ~ p . ~} 65\right.$; ? Möbius, '88, p. 242.

I 7. S. setiformis (Roth), Kütz. $\left(85^{-1}\right.$ 1० $\mu$ ):-West and West, '96, p. 377 ; ? Möbius, '93, p. I23; De Wildeman, '00, p. I I 5 .

I8. S. tropica, Kütz. (70-90 $\mu$ ?) :-? Möbius, '88, p. 242 ; Dickie, '81, p. 125 ; Martens, '70, p. 298 ; ? Möbius, '92, p. 24 ; Zeller, '73, p. I85; Zeller, '76, p. 427.

19. S. variabilis, De Wild. $(80-88 \mu)$ :-De Wildeman, '97, p. 83 ; De Wildeman, '00, p. I I 5 .

Although this list shows to some extent the preponderance of broad forms with several chloroplasts to the cells, it is of course merely an enumeration of species and records, and, as I have had frequent occasion to point out already, it gives us no idea of the relative abundance of individuals. Still, it gives some support to the view that, as observed in Ceylon, the tropics may in general have a relatively larger number of broad Spirogyras than our parts of the world. It is certainly striking in how many of the tropical floras we find almost only broad forms mentioned (cf., for instance, De Wildeman, '00, West and West, '97 A and '02 B). It may be that further observation may show that the above inference is not correct, but the matter is certainly worthy of attention.

There is little that is especially noticeable regarding the distribution of Spirogyra in the tropics, and it is probable that most of the species will 
be found to have a fairly wide range. It is noticeable that, although the algal flora has received considerable attention, only sterile Spirogyras have as yet been recorded from the Sandwich Islands. There are no records at all in Volken's algal collections from the Carolines, although they are so scanty that not much weight can be attached to this point (Schmidle, '01 B). Schmidle ('97 B) does not record any Spirogyras from the tropical parts of Polynesia, but from the Samoa Islands (Schmidle, '97 E) sterile species again are known. The literature offers too few data as to habitat to enable one to say anything of general application on this subject. In Ceylon, Spirogyra was found most abundantly in smaller, absolutely stagnant pieces of water (small ditches, rice-fields, \&c.), and generally occurred in localities where it was more or less shaded either by a dense growth of aquatic Phanerogams or by the surrounding terrestrial vegetation.

So little is known about the significance of the infolded transverse walls found in many of the narrower species of Spirogyra that we are not in a position to understand the reasons for the scarcity of species exhibiting this phenomenon in tropical waters. The infolding is usually looked upon as a mechanism for the disjunction of the cells of a filament, but from this point of view its scarcity in the tropics is inexplicable. Since it is mostly found in quite narrow forms, the rarity of these latter may be responsible, although that does not seem very likely.

In comparison to Spirogyra the other genera of Zygnemaceae play a very small part in the tropics; that is, however, the same relation as obtains in our flora. There are records of a considerable number of species of Mongeotia and Zygnema (incl. Zygogonium), also Gonatonema (G. tropicum, W. and G. S. West) and Sirogonium (S. sticticum, Kütz.). All these four genera have also been met with in Ceylon. In addition to this we have the two monotypic genera Temnogametum, W. and G. S. West, and Pyxispora, W. and G. S. West, from Africa (West and West, '97 A). Debarya, Wittr., has not yet been recorded from the tropics.

\section{(vi) The Desmids of the Tropics.}

Diverse as the Desmid-flora of temperate waters is, it appears to be excelled in the tropics. There is quite an extensive literature dealing with floristic records of tropical Desmids, and I must refer to the same for details on this point. One cannot say that a group so abundant in our flora finds more favourable conditions of existence in the tropics, but it does appear that along certain lines evolution of form in the Desmids has surpassed itself in tropical waters.

The only object I have in view here in dealing with tropical Desmids is to point out the important part which filamentous forms play. In our flora filamentous Desmids are distinctly rare, Hyalotheca dissiliens, Bréb., and Gymnozyga moniliformis, Ehrenb., perhaps being the two commonest. 
But examination of certain types of tropical waters (in Ceylon, especially small stagnant ditches and rock-pools) shows a wealth of such forms, which, although not very great in number of species, makes up for it by the large number of individuals. In such waters we also find many forms making attempts at filament-formation, which ordinarily exist as independent individuals (Micrasterias foliacea, Bail., species of Pleurotacnium, Triploceras, Euastrum, \&c.). The relative excess of filamentous Desmids in tropical waters comes out very plainly in comparing pools with a rich Desmid-flora from the lowlands and uplands (from around Nuwara Elija, alt. 6,coo feet and more) of Ceylon. The upland pools (in which the conditions of existence are semi-temperate) were found to be just as poor in filamentous forms as the waters of temperate regions. I have elsewhere ${ }^{1}$ suggested that we may again find an explanation for this phenomenon in the relative aeration of the water, the presence of little dissolved oxygen appearing to encourage filament-formation. This is a suggestion ${ }^{2}$ which must be left to experiment for verification, but it would certainly explain the relative abundance of filamentous Desmids in tropical waters. The same theory also accounts for the abundance of filamentous Diatoms in hot springs (cf. p. 253).

In turning our attention to the literature with reference to the point just discussed, I know of no more striking example to illustrate it than the records in Borge's paper on Australian freshwater Chlorophyceae (Borge, '96). The Algae enumerated in this paper are partly tropical and partly extra-tropical; of the sixteen species of filamentous Desmids recorded, thirteen are from tropical habitats, six only from extra-tropical localities. In further illustration of the same feature we may notice the number of species of filamentous Desmids in some of the more complete tropical algal floras, viz. Borge, '03 (sixteen species); De Wildeman, '00 (eleven species and numerous varieties); Joshua, '86 (thirteen species) ; Nordstedt, '80 (seven species and numerous varieties); Raciborski '95 (twelve species); Schmidle, '03 A (seven species); Turner, '92 (twenty-six species); West and West, '02 B (twenty-one species). It is, of course, possible that there are regions of the tropics in which filamentous Desmids are not as important as they no doubt are in certain waters in Ceylon, but I think it more probable that the lack of records in many of the floras is due to the material not having been collected from habitats in which these Desmids flourish. Small collections of stagnant water are apparently the most favourable; this is also shown by the large number of filamentous forms found amongst the Desmids, which live in the bladders of tropical species of Utricularia (cf. especially Raciborski, '95, p. 30 ; Nordstedt, '80).

1 Proc. Roy. Soc., Ser. B, vol. 1xxix, I907.

2 This theory is based on Senn's observations on colonial Protococcales (Bot. Zeitung, Bd. lvii, I899, p. 97). 


\section{(vii) The Oedogoniaceae in the Tropics.}

It has already been pointed out above that the species of Oedogonium found in the freshwaters of the tropics are prevalently narrow forms. This fact is very striking if we examine the literature. Thus the following species have filaments, whose diameter is Io $\mu$ or $\operatorname{less}^{1}:-$

A. I. Oedogonium angustissimum, W. and G. S. West $(\mathbf{I} \cdot 8-2 \mu)$ :-West and West, '97 A, p. 6.

\begin{tabular}{|c|c|c|}
\hline & & -8 \\
\hline & & $\begin{array}{l}\text { cryptoporum, Wittr. }(5-7.5 \mu):- \text { West and West, '02 } \mathrm{A} \text {, } \\
\text { p. } 5_{5} 8 \text {; West and West, '97 ^, p. } 4 \text {. }\end{array}$ \\
\hline . & " & $\begin{array}{l}\text { cryptoporum, Wittr., var. vulgare, Wittr. }(6.5-10 \mu): \text { West } \\
\text { and West, '02 в, p. г2 } 7 \text {. }\end{array}$ \\
\hline . & " & $\begin{array}{l}\text { elegans, W. and G. S. West }(6-8.5 \mu):- \text { West and West, } \\
02 \text { в, p. г } 28 \text {. }\end{array}$ \\
\hline 6. & " & excisum, Wittr. et Lund $(3 \cdot 5-5 \cdot 5 \mu):-$ Nordstedt, ' 80 , p. $\mathbf{3}$. \\
\hline & " & $\begin{array}{l}\text { Franklinianum, Wittr. }(8-\mathbf{1} 2 \mu) \text { :-Möbius, '93, p. I } 8 \text {; De } \\
\text { Wildeman, '00, p. 51. }\end{array}$ \\
\hline 8. & ," & $\begin{array}{l}\text { gracillimum, Wittr. et Lund }(6.5-7 \mu) \text { :-West and West, } \\
97 \mathrm{~A} \text {, p. } 4 \text { (f. major). }\end{array}$ \\
\hline ). & " & Howardii, G. S. West $\left(7 \cdot 5^{-1}\right.$ I $\left.\mu\right)$ :-West, '04, p. 28 I. \\
\hline & ", & $\begin{array}{l}\text { Itzigsohnii, De Bary }(4 \cdot 8-5 \cdot 7 \mu) \text { :-West and West, '97 } \\
\text { p. } 4 \text { (var. minor). }\end{array}$ \\
\hline & ", & $\begin{array}{l}\text { longicolle, Nordst. }(4-6 \mu) \text { :-West and West, '02 в, p. I } 28 \text {; } \\
\text { Nordstedt,'78, p. } 20 \text {; Lemmermann, '05, p. } 633 \text {. }\end{array}$ \\
\hline & " & $\begin{array}{l}\text { longicolle, Nordst., var. } \beta \text {. senegalensis, Nordst. }(5-7.5 \mu):- \\
\text { Nordstedt, '80, p. I3; Lagerheim, '93, p. I55; West } \\
\text { and West, '02 в, p. I28; Schmidle, '95, p. 294. }\end{array}$ \\
\hline • & " & $\begin{array}{l}\text { mammiferum, Wittr. }(7 \cdot 5 \mu):- \text { West and West, } 97 . \mathrm{A}, \mathrm{p} . \\
\quad \text { (sub } O \text {. huillense, W. and G. S. West). }\end{array}$ \\
\hline & " & ):-Lemmermann, '05, p. 633 . \\
\hline & " & 02 в, p. 127. \\
\hline & " & platygynum, Wittr. $(5-5 \cdot 7 \mu):-$ West and West, '02 в, p. I 27 \\
\hline & " & $\begin{array}{l}\text { pusillum, Kirchner }(3-8 \mu) \text { :-Lemmermann, '06, p. I } \\
\text { Lagerheim, '93, p. I55 (sub O. africanum, Lagerh.). }\end{array}$ \\
\hline & " & pyrulum, Wittr. $(8-\mathrm{I}$ г $\cdot 5 \mu)$ :-West and West, '02 в, р. г 27 \\
\hline & " & $\begin{array}{l}\text { reticulatum, W. and G. S. West }(7 \cdot 5-8 \mu):- \text { West and } \\
\text { 02 в, p. I } 29 .\end{array}$ \\
\hline & " & 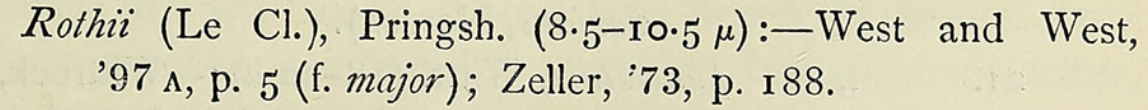 \\
\hline & & ] \\
\hline
\end{tabular}

1 This list has been revised according to Hirn's monograph (Act. Soc. Scient. Fennicae, t. xxvii, No. I, I900; and t. xxxiv, No. 3, I906). The measurements are taken from the actual records, wherever they were given; otherwise from Hirn. 
2. Oedogonium Sancti Thomae, Wittr. et Cleve $(7-\mathbf{r} 5 \mu)$ :-Wittrock, '78, p. I $4 \mathrm{I}$.

23. " $\quad$ tapeinosporum, Wittr. $(2 \cdot 7-5 \mu):-W i t$ rock, '78, p. I 40.

24. ", tapeinosporum, Wittr., var. angolense, W. and G. S. West $(3 \cdot 8-4.5 \mu):$-West and West, '97 A, p. 5 .

25. ", Warmingianum, Wittr. $(8-9 \mu)$ :-Wittrock, '78, p. I 40.

B. In the following species the diameter is $20 \mu$ or less :-

I. Oedogonium acrosporum, De By. (I $3^{-2}$ I $\mu$ ):-Wille, '84, p. 25 ; Lagerheim, '93, p. I 55 .

2. $\quad$,

3. $\quad$,

4.,

5.,

6.

7 .

8.

9. ,

IO.

I I.

I 2.

I3. ,

I 4. ,

I 5 . , ,

I6.

17.

I 8.

19.

20.

21.

22.

23.

24. acrosporum, De By., var. majusculum, Nordst. (I 4-2 I $\mu$ ) :-

Nordstedt, '78, p. 2 I ; Lemmermann, '05, p. 633.

areolatum, Lagerh. (I 7-2 I $\mu$ ):-Lagerheim, '90, p. 2 and $\mathbf{I}$ I. brasiliense, Borge (16-2 $2 \mu)$ :-Borge, '99, p. 4.

Braunii, Kütz. (1 $\left.3^{-\mathbf{r}} 5 \mu\right)$ :-Zeller, '73, p. 188 ; Lagerheim,

' 90, p. 2.

Cleveanum, Wittr. ( I $^{-2} 5 \mu$ ):-Schmidle, '01 в, p. 344.

crispum (Hass.), Wittr. (12-16 $\mu$ ):-Turner, '92, p. I63 ;

Wittrock, '78, p. I 33 .

crispum (Hass.), Wittr., var. havaiense, Nordst. (12-16 6 ):-

Nordstedt, '78, p, 20 ; Lemmermann, '05, p. 633.

crispum (Hass.), Wittr., var. Uruguayense, Magn. et Wille

$\left(\mathrm{I} 3.5^{-1} 5 \mu\right)$ :-West and West, '97 A, p. 4.

dictyosporum, Wittr. (I I-I6 $\mu$ ):-Wittrock, '78, p. I34.

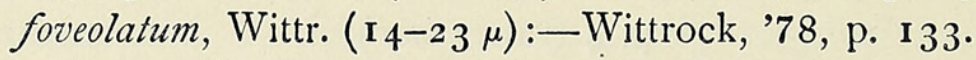

globosum, Nordst. (Io-1 $4 \mu$ ) :-Nordstedt, '78, p. 20 ; Lemmermann, '05, p. 633 ; Wille, '03, p. 93.

laetevirens, Wittr. (1 2-1 $3 \mu$ ):-Zeller, '76, p. 427 ; Wittrock, '78, p. I35.

londinense, Wittr. $\left(\mathbf{1} 2 \cdot 5^{-\mathbf{r} 3.5 \mu)}\right.$ :- West and West, '97 A, p. 6.

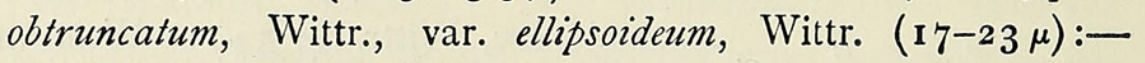
Wittrock, '78, p. I 4 I.

Paulense, Nordst. et Hirn (го-1 $4 \mu$ ):-Schmidle, '01 в, p. 344 .

Pithophorae, Wittr. (10-13 $\mu$ ):-Wittrock, '78, p. I 4 I. pluviale, Nordst. ( $19-25 \mu)$ :-West and West, '02 a, p. I6o. Pringsheimii, Cram. (I $0-15 \mu$ ):-Nordstedt, '78, p. 2 I (sub $O$. pachydermatosporum, Nordst.).

Pringsheimii, Cram., var. Nordstedtii, Wittr. (I2-I4 4 ):Schmidle, '97 E, p. 260 (sub O. Pringsheimii, var. varians, Nordst.).

punctatum, Wittr. (I 8-22 $\mu$ ):-Wittrock, '78, p. I4 $4^{2 .}$

Sodiroanum, Lagerh. $(2 \circ \mu)$ :-Lagerheim, '90, p. 2.

stellatum, Wittr. ( $\left.13 \cdot 5^{-1} 7 \mu\right)$ :-West and West, '02 в, p. $\mathbf{2} 28$.

undulatum (Bréb.), A. Br. (14-16 4 ):-Borge, '99, p. 4;

Turner, '92, p. 163 ; Borge, '96, p. 4 . 
25. Oedogonium undulatum (Bréb.), A. Br., var. senegalense, Nordst. (1 4-20 $\mu$ ): Nordstedt, '80, p. I 3 .

26. ", Welwitschii, W. and G. S. West $(\mathrm{r} 7-24 \mu)$ :-West and West, ' 97 A, p. 5 .

C. In the following species the diameter is $30 \mu$ or less:-

I. Oedogonium cyathigerum, Wittr., f. ornatum (Nordst.), Hirn $(2 \mathbf{I}-30 \mu)$ :Wittrock, '78, p. 134 .

2. " cyathigerum, var. hormosporum (W. and G. S. West), Hirn $(22-3 \circ \mu)$ :-West and West, '97 A, p. 5 (sub O. hormosporum, W. and G. S. West; in stagnis pr. Catumba); Schmidle, '03 A, p. 86 (ditch near Langenburg).

3. " indicum, Hirn. $(20-25 \mu)$ :-Schmidle, '00 A, p. I60 (no locality given).

4. $\quad$ oboviforme, Wittr. $\left(2 \mathrm{I}-3^{2} \mu\right)$ :-Wittrock, '78, p. I 40.

5. $" \quad$ plagiostomum, Wittr., var. gracilius, Wittr. $(\mathbf{2 2 - 2 5 \mu ) : - ~}$ Wittrock, '78, p. $\mathbf{1}^{2}$.

6. „ spirale, Hirn, var. acutum, W. and G. S. West $(22-25 \mu)$ :-

West and West, '02 в, p. 128 (rice-fields).

7. ", Wolleanum, Wittr. $(2 \mathrm{I}-3 \circ \mu)$ :-Schmidle, '00 A, p. 160 (no locality given).

D. The diameter is below $40 \mu$ in :-

I. Oedogonium dioicum, Carter $(3 \mathrm{I}-35 \mu)$ :-West and West, '02 A, p. I 59 (stagnant water).

2. "Landsboroughi (Hass.), Wittr. $(3 \mathrm{I}-40 \mu)$ :-Schmidle, '00 A, p. 160 (no locality given); Zeller, ' 73, p. I 88.

3. $\quad$ mexicanum, Wittr. $(34-40 \mu)$ :-Wittrock, '78, p. $3^{8}$.

E. The diameter is over $40 \mu$ in :-

I. Oedogonium fabulosum, Hirn, var. maximum, W. and G. S. West $(83-93 \mu)$ :-West and West, '02 A, p. I59 (sub $O$. maximum, W. and G. S. West; stagnant water).

2. " Kurzii, Zeller $\left(44-5^{2} \mu\right)$ :-Zeller, '73, p. I 89 (marsh).

3.,$\quad$ suboctangulare, W. and G. S. West $(50-54 \mu)$ :-West and West, '02 в, p. 127 (rice-fields).

The list shows the great prevalence of narrow forms; by far the majority (viz. $5 \mathrm{I}$ ) are less than $20 \mu$, and only thirteen species exceed these dimensions. I have above indicated that $\mathrm{I}$ am inclined to explain this as a result of the small amount of dissolved oxygen in the water. In all the forms whose filaments are more than $20 \mu$ in width data as to habitat have been added, where these are available. These data, however, do not show that the broad forms in question are found in anything but stagnant water, so that it does not appear that they have got over the difficulties of poor aeration by frequenting special habitats. $O$. suboctangulare, to judge by the figures (West and West, '02 B, Pl. XVII, Figs. 1, 2), has exceptionally thin walls, and the same is true to a less extent of $O$. fabulosum, var. 
maximum (cf. West and West, '02 A, Pl. IV, Figs. 39-4I). Possibly the success of these few broad forms lies in this feature. It is, however, most requisite that the tropical habitats of the broad species of Oedogonium should be carefully studied.

The genus Bulbochaete is not very well represented, but it is a form which may fairly easily escape notice. There is nothing, as far as I am aware, of particular interest attaching to its occurrence in tropical waters.

\section{The Freshwater Florideae of the Tropics.}

Since the Florideae, like the Cyanophyceae, are provided with a protective pigment (in the form of phycoerythrin and its modifications), we might expect this group to be a successful one in the tropics. It is, however, an essentially marine group, and has but few freshwater representatives, all of which are not very common in our parts of the world. In the tropics, on the other hand, they seem to be not at all uncommon, as shown by the following enumeration of records :-

I. Batrachospermum angolense, W. and G. S. West (West and West, '97 A, p. 2 ; West and West, '02 в, p. г 25); B. Bohneri, Schmidle (Schmidle, '99, p. 2 ; Schmidle, '02 A, p. 67); B. bornense, Zanardini (Zanardini, '72, p. 146); B. gracillimum, W. and G. S. West (West and West, '97 A, p. 2); B. huillense, Welw. MS. (West and West,' 97 A, p. 3) ; B. moniliforme, Roth (Gutwinski and Chmielewski, '06, p. 2 ; Möbius, '90, p. 1070; Martens, '70, p. 299; Möbius, '92, p. 22 ; Zeller, '73, p. г92); $B$. moniliforme, vars. proliferum and nodiflorum (Dickie, '81, p. 33); B. nigrescens, W. and G. S. West (West and West, ' 97 A, p. 2); B. Puiggarianum, Grun. (Möbius, '92, p. 22); B. Schrvackeanum, Möbius (Möbius, '92, p. х8); B. vagum, Ag. (Möbius, '92, p. 22); B. villosum, Zanardini (Zanardini, '72, p. 147).

2. Chantransia chalybea, Fr. (Möbius, '95, p. I 74); C. pulvinata, Schmidle (Schmidle, '00 A, p. 188; Schmidle, '00 B, p. 79); C. roseola, Zeller (Zeller, '73, p. 192)

3. Compsopogon chalybeus, Kütz. (Möbius, '88, p. 222 ; Möbius, '90, p. 1070; Zeller, '76, p. 427); C. fuscatus, Zanardini (Zanardini, '72, p. 149); C. leptoclados Mont. (Dickie, '81, p. I23; Martens, '71, p. 144).

4. Hildenbrandtia angolensis, Welw. MS (West and West, '97 A, p. 3); $H$. rivularis (Liebm.), J. Ag. (West and West, '97 A, p. 3 ; Hariot, '91, p. I 220 ).

5. Thorea flagelliformis, Zanardini (Zanardini, '72, p. 148); T. Gaudichaudii, Ag. (Schmidle, '00 D, p. 24); T. ramosissima, Bory (De Wildeman, '00, p. 397); $T$. Traili, Dickie (Dickie, '81, p. I 23 ).

Lemanea does not appear to have been recorded from the tropics up to the present.

As in our parts of the world, the freshwater Florideae of the tropics are found prevalently in running water, and appear to occur most commonly in mountainous regions. I have not been able to settle whether they are ever found in the actual lowlands of the tropics. 


\section{SUMMARY.}

The more important conclusions or suggestions brought forward in the present paper may be briefly summarized as follows :-

(i) There is some evidence to show that in the damp tropics there is always a very extensive subaerial algal covering, equal to or perhaps even surpassing that examined by the author in Ceylon.

(ii) The subaerial algal growth in Ceylon consists almost entirely of Cyanophyceae, and there is evidence in the literature that in other parts of the tropics this group is equally predominant in the subaerial algal flora. There are not very many records of green subaerial forms in the literature (see however iv), and it is probable that they play a very small part in the tropics.

(iii) The Cyanophyceae are probably an essentially tropical group, and it is not impossible that they may be the descendants of primitive algal forms, which existed in earlier periods under conditions analogous to those found in the damp tropics at the present day.

(iv) Trentepohlia is the only genus of green Algae that is really successful in the subaerial flora (apart from other members of the Chroolepideae, which have become epiphyllous, and from the parasitic genera Phyllosiphon and Phytophysa.)

(v) In the submerged algal flora of tropical freshwaters the Cyanophyceae also constitute a very important element, though not as preponderant as in the subaerial flora. They are equally important in the Plankton.

(vi) The freshwater algal flora of the tropics is composed of forms in which narrow filaments are much more abundant than broad ones, a fact which is brought into relation with the small amount of dissolved oxygen in the water. Exceptions are constituted by Pithophora and Spirogyra, especially by the latter.

(vii) Cladophora and Rhizoclonium are very poorly represented in tropical freshwaters in comparison to their abundant occurrence in our parts, and there is good evidence to show that in most cases they favour wellaerated (e.g. running) water. The chief representative of Cladophoraceae in the tropics is Pithophora, which appears to be an essentially tropical genus.

(viii) Vaucheria is very rare in the tropics. This refers especially to the aquatic species, but the terrestrial ones are not much commoner. Botrydium is equally rare. It is possible that the peculiar assimilatory process in these two forms is responsible (the same applies to the Confervales).

(ix) The Confervales are not very well represented, the most abundant form being Ophiocytium. Conferva is not well represented, and tends to be restricted to well-aerated water.

(x) In the case of the Ulotrichales it is not quite evident at present 
whether they attain an adequate development in tropical freshwaters, but there are slight indications to the contrary.

(xi) The genus Spirogyra is even more abundant in the tropics than it is with us. The species so far recorded are mainly broad forms with two or many chloroplasts in their cells. Forms with infolded end-walls are strikingly rare. The other genera of Zygnemaceae are not very abundantly represented.

(xii) There is a marked filamentous tendency amongst the Desmids of tropical waters (especially in certain kinds of stagnant water), and it is suggested that this may again be due to the poor aeration of the water.

(xiii) The genus Oedogonium is very abundant in the tropics, but is mainly represented by species with narrow filaments.

(xiv) Freshwater Florideae appear to be not at all uncommon in the tropics.

In conclusion, I should like to mention that I am fully aware of the speculative basis of a great part of the matter contained in this paper; preliminary experiments are, however, already in progress with a view to testing the accuracy of many of the suggestions. The investigation is in too early a stage at present to admit of any communication on the subject. I should also state that I am indebted to the Government Grant Committee of the Royal Society for the grant which made it possible to investigate the freshwater algal flora of Ceylon-an investigation which has been the chief stimulus for the present paper.

University College, London.

February 18, 1907.

\section{BIBLIOGRAPHY. ${ }^{1}$}

1. Askenasy ('89) : E. Askenasy, Algen, mit Unterstützung der Herm E. Bornet, A. Grunow, P. Hariot, M. Möbius, O. Nordstedt, in Die Forschungsreise S.M.S. 'Gazelle' in den Jahren $I 874$ bis $18 ; 6$. IV. Teil : Botanik. Berlin, I 899 , pp. I -58 (only partly tropical)。

2. Boergesen ('90): F. Boergesen, Desmidieae, in 'Symbolae ad floram Brasiliae centralis cognoscendam'. Vid. Meddelels. fra d. Nat. Foren. i. Kjфbenhavn, I89o, pp. $24-53$.

1 I have already pointed out that this bibliography, though great pains have been taken to include all the important papers dealing with the tropical freshwater and subaerial algal flora, is not exhaustive. Very few of the older papers are included, and of recent ones many minor contributions, not bearing on the main points of the present paper, have been omitted. I have also not taken into account the records in De Toni's 'Sylloge,' since a considerable number would have been duplicates of those already given. Nor have any exsiccata been considered for the same reasons. Messrs. Wittrock, Nordstedt and Lagerheim's 'Algae aquae dulcis exsiccatae' do indeed contain a certain number of records of tropical forms, which, as far as I am aware, are not published elsewhere, but reference to the recent general index (published, Lund, 1903) will show them at a glance.

Certain papers marked with a star were not considered in all points sufficiently distinct or precise to be taken into account in all of the lists compiled in the course of my paper; omission of data from them in certain cases must not therefore be attributed to negligence on my part. 
3. Bohlin ('97) : K. Bohlin, Die Algen der ersten Regnell'schen Expedition. I. : Protococcoideen. Bih. Sv. Vet.-Ak. Handl., xxiii, Afd. III, No. 7, 1897.

4. Borge ('96) : O. Borge, Australische Süsswasserchlorophyceen. Bih. K. Sv. Vet.-Ak. Handl., xxii, Afd. III, 1896, No. 9 (only partly tropical).

5. ('99): O. Borge, Ueber tropische und subtropische Süsswasser-Chlorophyceen. Bih. K. Sv. Vet.-Ak. Handl., xxiv, Afd. III, I899, No. I2 (only partly tropical).

6. ('03): O Borge, Die Algen der ersten Regnell'schen Expedition. II.: Desmidiaceen, III.: Zygnemaceen und Mesocarpaceen. Arkiv f. Bot. Stockholm, I903, Bd. i, p. 7 I et seq. (only partly tropical).

7. ('06): O. Borge, Algen aus Argentina und Bolivia. Arkiv för Botanik, K. Sv. Vet.-Akad. i Stockholm, Bd. vi, 1906, No. 4 (only partly tropical).

8. Borzi ('92): A. Borzi, Alghe d'acqua dolce della Papuasia raccolte su cranii umani dissepolti. Nuovo Notarisia, Ser. $3,189^{2}$, p. 35 et seq.

9. Coнn ('79) : F. Cohn, Desmidiaceae Bongoenses. Festschr. Naturf. Ges. Halle a/S., I879, p. 26 I et seq.

10. Cunningham ('80):-D. D. Cunningham, On Mycoidea parasitica, a new genus of parasitic Algae. Trans. Linn. Soc., Ser. 2, vol. i, 1880.

11. De Ton ('89): G. B. De Toni, Sylloge Algarum omnium hucusque cognitarum. Vol. i. : Chlorophyceae. Patavii, I889.

12. ('91) : G. B. De Toni, Ueber eine neue Tetrapedia-Art aus Afrika. Hedwigia, xxx, 1891, pp. 194-6.

13. ('92): G. B. De Toni, Algae abyssinicae a cl. Prof. O. Penzig collectae. Malpighia, v. I $891-92$, pp. 261-73.

14. De Toni and Saccardo ('90): G. B. De Toni and F. Saccardo, Revisione di alcuni generi di chloroficee epifite. Nuovo Notarisia, 1890.

15. De Wildeman ('88) : É. De Wildeman, Sur quelques formes du genre Trentepohlia. ComptesRendus Soc. Roy. Bot. de Belgique, xxvii, I888, pp. 178-82 (also loc. cit. xxviii, 1889 , pp. $67-70)$.

16. Comptes-Rendus, Soc. Roy. Bot. de Belgique, xxviii, I889, pp. 6-10.

17. ('91): É. De Wildeman, Les Trentepohlia des Indes Néerlandaises. Ann. Jard. Bot. Buitenzorg, ix, I89I, pp. I $27-42$.

18. ('94): E. De Wildeman, Notes sur quelques espèces du genre Trentepohlia (Martius). Annales (Mémoires) Soc. belge de Microscopie, xviii, 1894, p. 5 et seq. (also loc. cit., xxi, 1897, p. 95 et seq.).

19. ('97): E. De Wildeman, Algues rapportées par M. J. Massart d'un voyage

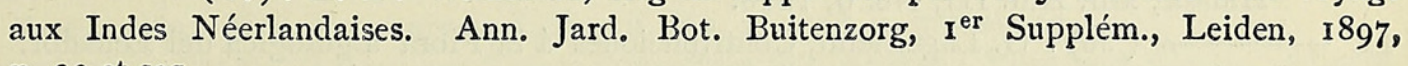
p. 32 et seq.

20. L ('00): É. De Wildeman, Les Algues de la flore de Buitenzorg. Leiden, I 900. (Cf. also Prodrome de la flore algologique des Indes Néerlandaises, Batavii, I 897-99).

21. Dickie (75*): G. Dickie, On the Algae of Mauritius. Journ. Linn. Soc. Bot., vol. xiv, I875, p. 190 et seq.

22. ('80): G. Dickie, Notes on Algae from Lake Nyassa, E. Africa. Journ. Linn. Soc. Bot., vol. xvii, r 880, p. 281 et seq.

23. - (' $\left.81^{*}\right)$ : G. Dickie, Notes on Algae from the Amazons and its Tributaries. Journ. Linn. Soc. Bot., vol. xviii, I881, p. 123 et seq.

24. Gomont ('02) : M. Gomont, Myxophyceae hormogoneae, in J. Schmidt, Flora of Koh Chang. Botanisk Tidsskrift, xxiv, I902, p. 202 et seq.

25. Grunow ('65): A. Grunow, Ueber die von Herrn Gersterberger in Rabenhorst's Decaden ausgegebenen Süsswasser-Diatomaceen und Desmidiaceen von der Insel von Banka, etc. Rabenhorst, Beitr. z. Kenntn. d. Verbreit. d. Algen, II. Heft, I865 (see also Hedwigia, iv, I 865 , p. 124 et seq.).

26. ('67): A. Grunow, Algen, in Reise seiner Majestät Fregatte 'Novara' um die Erde, Botan. Theil, I. Bd., Wien, 1867 , p. I et seq. (only partly tropical).

27. Gutwinski ('02 A) : R. Gutwinski, De Algis a Dr. M. Raciborski anno 1899 in insula Java collectis. Bull. Internat. Ac. Sci. Cracovie., No. 9, November, 1902, p. 575 et seq.

28. $\left({ }^{\prime} 02 \mathrm{~B}\right):$ R. Gutwinski, Additamenta ad floram algarum Indiae Batavorum 
cognoscendam. Algae a cl. Dre. M. Raciborski in montibus vulcanis Krakatau et Slamat anno 1897 collectae. Verh. u. Sitzber. Ak. Wiss. Krakau, xxxix, 1902, p. 287 et seq. (not seen).

29. Gutwinski and Chmielewski ('06): R. Gutwinski and Z. Chmielewski, Contribution à l'étude des Algues du Kameroun. Ann. de Biologie lacustre, i, I906.

30. Hariot ('89) : P. Hariot, Notes sur le genre Trentepohlia, Martius. Journ. de Botanique, iii, 1889 , p. 345 et seq. (also loc. cit., iv, 1890, p. 85 et seq.).

31. ('91): P. Hariot, Quelques Algues du Brésil et du Congo. Notarisia, vi, I891, p. 1217 et seq.

32. ('92): P. Hariot, A propos des Trentepohlia des Indes Néerlandaises. Journ. de Botanique, vi, I 892 , pp. II 4 -I 6 .

33. ('95) : P. Hariot, Liste des Algues recueillies au Congo par M. H. Lecomte. Journ. de Botan., ix, 1895, pp. 242-4.

34. Henriques ('86): J. Henriques, Contribuições para o estudo da Flora d'Africa. Bol. Soc. Broter., iv, I 886 (I887), p. 2 I 7 et seq.

35. Heydrich ('94): F. Heydrich, Beiträge zur Kenntniss der Algenflora von Ost-Asien, besonders der Insel Formosa, Molukken- und Liu-Kin-Inseln. Hedwigia, xxxiii, 1894, p. 267 et seq.

36. Hieronymus ('95): G. Hieronymus, Algen, in Engler, Die Pflanzenwelt Ost-Afrikas und der Nachbargebiete, Theil c, Berlin, 1895 .

37. JAdin ('93): F. Jadin, Algues des îles Mascareignes récoltées en I890 (Nostocacées). Bull. Soc. Bot. de France, t. xl, 1893, pp. cxlviii-clxxiii.

38. Joshua ('86): W. Joshua, Burmese Desmidieae, with Descriptions of new Species occurring in the neighbourhood of Rangoon. Journ. Linn. Soc. Bot., vol. xxi, 1886, p. 634 et seq.

39. Karsten ('91): G. Karsten, Untersuchungen über die Familie der Chroolepideen. Ann. Jard. Bot. Buitenzorg, x, I89I, p. I et seq.

40. Koorders ('01): S. H. Koorders, Notiz über die dysphotische Flora eines Süsswassersees in Java. Naturk. Tijdschr. Ned. Indie, lxi, I9or, No. 3 .

41. Lagerheim ('85): G. Lagerheim, Bidrag till Amerikas Desmidié-flora. Öfvers. af K. Sv. Vet.-Ak. Förhandl., 1885, No. 7 , p. 225 et seq.

42. ('87): G. Lagerheim, Algologiska Bidrag. II. : Ueber einige Algen aus Cuba, Jamaica und Puerto-Rico. Bot. Notiser, 1887 , pp. I93-9.

43. _ ('88): G. Lagerheim, Ueber Desmidiaceen aus Bengalen nebst Bemerkungen über die geographische Verbreitung der Desmidiaceen in Asien. Bih. till K. Sv. Vet.-Ak. Handl., xiii, Afd. III, No. 9, I888.

44. - ('90): G. Lagerheim, Contribuciones á la Flora algológica del Ecuador. Añales de la Universidad de Quito, iv, I89o, I6 pp. (separate copy).

45. ('92): Ueber einige neue Arten der Gattung Phyllosiphon, Kühn. Nuovo Notarisia, Ser. iii, I892, pp. I20-4.

46. ('93): Chlorophyceen aus Abessinien und Kordofan. Nuovo Notarisia, Ser. iv, I 893 , p. I 53 et seq.

47. Lemmermann ('99) : E. Lemmermann, Planktonalgen, in H. Schauinsland, Ergebnisse einer Reise nach dem Pacific (1896-97). Abhandl. Nat. Ver. Bremen, Bd. xvi, I900, p. 3 I 3 et seq.

48. - ('05): E. Lemmermann, Die Algenflora der Sandwich-Inseln, in Ergebnisse einer Reise nach dem Pacific, H. Schauinsland 1896-97. Engler's Bot. Jahrb. xxxiv, 1905, p. 607 et seq.

49. ('06): E. Lemmermann, Ueber die von Herrn Dr. Walter Volz auf seiner Weltreise gesammelten Süsswasseralgen. Abhandl. Nat. Ver. Bremen, Bd. xviii, I906, p. 143 et seq.

50. MaGnus und Wille ('82): P. Magnus and N. Wille, Untersuchung der auf der Süsswasserschlange Herpeton tentaculatum, Lacep. aus Bangkok in Siam wachsenden Algen (Cladophora ophiophila, M. et W.). Sitz.-ber. Ges. Nat. Freunde, Berlin, I882 (not seen).

51. Martelli ('86): U. Martelli, Florula bogosensis : Enumerazione delle piante dei Bogos raccolte dal Dott. O. Beccari nell' anno I 870 con descrizione delle specie nuove o poco note. Firenze I 886 (Algae by Grunow, p. I 50 et seq.). 
52. Martens ('66*): G. v. Martens, Die Tange, in Die Preussische Expedition nach Ost-Asien, Botan. Theil, Berlin, I866, p. I9 et. seg., and II I, I I 2.

53. - ('70): G. v. Martens, Conspectus Algarum Brasiliae hactenus detectarum. Vid. Medidelels. Nat. For. i Kj申benhavn, 1870, pp. 297-314.

54. ('71): G. v. Martens, Algae Brasilienses circa Rio de Janeiro a clar. A. Glaziou, horti publici directore, botanico indefesso, annis 1869 et 1870 collectae. Vid. Meddelels. Nat. For. i Kjфbenhavn, I87 I, p. I44 et seq.

55. MöвıUS ('88): M. Möbius, Ueber einige in Portorico gesammelte Süsswasser- und Luftalgen. Hedwigia, xxvii, $1888, \mathrm{p} .22 \mathrm{I}$ et seq.

56. ('89): M. Möbius, Bearbeitung der von H. Schenck in Brasilien gesammelten Algen. Hedwigia, xxvii, 1889, p. 309 et seq.

57. ('90): M. Möbius, Algae Brasilienses a cl. Dr. Glaziou collectae. Notarisia, v, 189o, p. 1065 et seq.

58. ('92) : M. Möbius, Ueber einige brasilianische Algen. Ber. deutsch. Bot. Ges., vol. $\mathrm{x}, 189^{2}$, pp. I $7-26$.

59. ('93): M. Möbius, Beitrag zur Kenntnis der Algenflora Javas. Ber. deutsch. Bot. Ges., vol, xi, I893, p. II 8 et seq.

60. ('95): M. Möbius, Ueber einige brasilianische Algen. Hedwigia, xxxiv, 1895, p. I73 et seq.

61. Montagne ('39): C. Montagne, Cryptogamae brasilienses, etc. Ann. Sci. Nat., Bot., Sér. II, vol. xii, 1839 , p. 45 .

62. Nordstedt ('69) : C. F. O. Nordstedt, Desmidiaceae, in E. Warming, Symbolae ad floram Brasiliae centralis cognoscendam. Vid. Meddelels. Nat. For. i Kjpbenhavn, 1869, Nos. I 4, I 5 , pp. I95-234.

63. ('77): C. F. O. Nordstedt, Nonnullae algae aquae dulcis brasilienses. Öfvers. Sv. Vet.-Ak. Förhandl., xxxiv, 1877 , No. 3 , p. I 5 et seq.

64. ('78): C. F. O. Nordstedt, De Algis aquae dulcis et de Characeis ex insulis Sandvicensibus a Sv. Berggren 1875 reportatis. Minnesskrift., Lund, I 878 .

65. ('80): C. F. O. Nordstedt, De Algis et Characeis. I. : De Algis nonnullis, praecipue Desmidieis, inter Utricularias Musei Lugduno-Batavi. Act. Univ. Lund, xvi, I879-80, Pt. II, No. iv, pp. I-20.

66. ('89): C. F. O. Nordstedt, De Algis et Characeis. III. De duabus novis speciebus Desmidiearum e Brasilia. Act. Univ. Lund, xxv, 1889.

67. - ('97): C. F. O. Nordstedt, Sötvattensalger från Kamerun. Botan. Notiser, r 897, p. r 3 I et seq.

68. Prain ('05*): D. Prain, The Vegetation of the Districts of Hughli-Howrah and the 24 Pergunnahs. Rec. Bot. Survey, India, iii, No. 2, I905, p. 328 et seq.

69. Rabenhorst ('55*): Beitrag zur Kryptogamenflora Süd-Afrikas : Pilze und Algen. Allgem. Deutsch. Naturhist. Zeit., i, I 855, pp. 280-3.

70. Raciborski ('95): M. Raciborski, Die Desmidieenflora des Tapakoomasees. Flora, Bd. $1 \times x \times i, 1895$, pp. $3^{0-5}$.

71. - ('00): M. Raciborski, Parasitische Algen und Pilze Javas. I, II, and III. Publ. by Bot. Inst. Buitenzorg, Batavia, 1900.

72. Schmidle ('95): W. Schmidle, Einige Algen aus Sumatra. Hedwigia, xxxiv, 1895, p. 293 et seq.

73. ('97 A): W. Schmidle, Algologische Notizen. II.: Conferva Sandvichensis, Ag. Kneucker's Allgem. Bot. Zeitschr., iii, 1897, pp. 3, 4 .

74. ('97 B): W. Schmidle, Algologische Notizen. III.: Einige neue und seltene Algen aus Polynesien. Kneucker's Allgem. Bot. Zeitschr., iii, I897, p. 57 et seq.

75. ('97 c): W. Schmidle, Vier neue von Professor Lagerheim in Ecuador gesammelte Baumalgen. Ber. deutsch. Bot. Ges., Bd. xv, 1897, p. $45^{6}$ et seq.

76. ('97 D): W. Schmidle, Epiphylle Algen nebst einer Pithophora und Dasya aus Nen-Guinea. Flora, lxxxiii, I897, p. 304 et seq.

77. - ('97 E): W. Schmidle, Süsswasseralgen, in F. Reinecke, Die Flora der SamoaInseln. Engler's Bot. Jahrb., xxiii, 1897, p. 253 et seq.

78. ('97 F): W. Schmidle, Einige Baumalgen aus Samoa. Hedwigia, xxxvi, 1897, p. 277 et seq. 
79. Schmidee ('98 A): W. Schmidle, Die von Professor Dr. Volkens und Dr. Stuhlmann in OstAfrika gesammelten Desmidiaceen. Engler's Bot. Jahrb., Bd. xxvi, I898, p. I et seq.

80. ('98 в) : W. Schmidle, Ueber einige von Prof. Lagerheim in Ecuador und Jamaika gesammelte Blattalgen. Hedwigia, xxxvii, 1898 , p. 6r et seq.

81. ('99): W. Schmidle, Algologische Notizen. VIII. : Batrachospermum Bohneri, Schmidle n.sp.; IX. : Phylloplax candelabrum, Schmidle n. gen. Knencker's Allgem. Bot. Zeitschr., v, I 899, pp. 2-4.

82. - ( $00 \mathrm{~A})$ : W. Schmidle, Ueber einige von Professor Hansgirg in Ostindien gesammelte Süsswasseralgen. Hedwigia, xxxix, 1900, p. I60 et seq.

83. - ( $100 \mathrm{~B})$ : W. Schmidle, Einige neue von Prof. Dr. Hansgirg in Vorderindien gesammelte Süsswasseralgen. Kneucker's Allgem. Bot. Zeitschr., vi, 1900, p. I7 et seq.

84. ('00 c): W. Schmidle, Drei interessante tropische Algen. Bot. Centralbl., lxxxi, I900, pp. 4I 7,4 I 8 .

85. ( in der Sïdsee (by K. Lauterbach and K. Schumann). Leipzig, 190I, p. I et seq.

86. ('01 A): W. Schmidle, Algen aus Brasilien. Hedwigia, xl, I9OI, p. 45 et seq.

87. ('01 в): W. Schmidle, Einige Algen, welche Prof. Dr. Volkens auf den Carolinen gesammelt hat. Hedwigia, xl, I90I, p. 343 et seq.

88. ('02 A): W. Schmidle, Beiträge zur Algenflora Afrikas. Engler's Bot. Jahrb., Bd. $\mathrm{xxx}, 1902, \mathrm{pp} \cdot 5^{8-68 .}$

89. ('02 B) : W. Schmidle, Schizophyceae, Conjugatae, Chlorophyceae, in A. Engler, Berichte über die botanischen Ergebnisse der Nyassa-See- und Kinga-Gebirgs-Expedition. Engler's Bot. Jahrb., Bd. xxx, I902, p. 240 et seq.

90. ('03 A): W. Schmidle, Algen, insbesondere solche des Planktons aus dem NyassaSee und seiner Umgebung. Engler's Bot. Jahrb., Bd. xxxii, I903, p. 54 et seq.

91. ('04 A): W. Schmidle, Das Chloro- und Cyanophyceenplankton des Nyassaund einiger anderer inner-afrikanischer Seen. Engler's Bot. Jahrb., Bd. xxxiii, 1904, p. I et seq.

92. ('04 B): W. Schmidle, Einige neue Algen aus Java und den Philippinen (gesammelt von A. Usteri, Zürich). Hedwigia, xliii, 1904, pp. 4I 4, 4I 5 .

93. Turner (' $\left.92^{*}\right)$ : W. B. Turner, Algae aquae dulcis Indiae orientalis. K. Sv. Vet.-Ak. Handl., Bd. $x x v$, No. 5,1892 .

94. Wallich ('60): G. C. Wallich, Descriptions of Desmidiaceae from Lower Bengal. Ann. Mag. Nat. Hist., Ser. 3, v, 1860 , p. 184 et seq.

95. WARD ('84): H. Marshall Ward, Structure, Development, and Life-history of a Tropical Epiphyllous Lichen. Trans. Linn. Soc., Ser. II, vol. ii, I 884.

96. West ('02): G. S. West, On some Algae from Hot Springs. Journ. of Bot., xl, 1902, p. 24 I et seq.

97. ('04): G. S. West, West Indian Freshwater Algae. Journ. of Bot., xlii, 1904, p. 28I et seq.

98. West and West ('93): W. and G. S. West, Algae from the West Indies. Journ. Linn. Soc. Bot., $x x x, 1893-5$, p. 264 et seq.

99. ('95): W. and G. S. West, A Contribution to our Knowledge of the Freshwater Algae of Madagascar. Trans. Linn. Soc. Bot., Ser. 2, v, I895, p. 4I et seq.

100. ('96): W. and G. S. West, Algae from Central Africa. Journ. of Bot., vol. xxxiv, 1896, p. 377 et seq.

101. of Bot., vol. $\mathrm{xxxv}, \mathrm{I} 897$, p. I et seq.

102. (' 97 B): W. and G. S. West, Desmids from Singapore. Journ. Linn. Soc. Bot., xxxiii, I897, p. I 56 et seq.

103. ('99): W. and G. S. West, A Further Contribution to the Freshwater Algae of the West Indies. Journ. Linn. Soc. Bot., xxxiv, I899, p. 279 et seq.

104. ('02 A): W. and G. S. West, Freshwater Chlorophyceae, in J. Schmidt, Flora of Koh Chang. Bot. Tidsskrift, xxiv, I902, p. I 57 et seq.

105. ('02 B): W. and G. S. West, A Contribution to the Freshwater Algae of Ceylon. Trans. Linn. Soc. Bot., Ser. 2, vi, 1902, p. I 23 et seq. 


\section{Algal Flora of the Tropics.}

106. Wille ('84): N. Wille, Bidrag till Sydamerikas Algflora. Bih. K. Sv. Vet.-Ak. Handl., viii, No. 18,1884 .

107. ('03) : N. Wille, Ueber einige von J. Meynhardt in Südafrika gesammelte Süsswasseralgen. Österr. Bot. Zeitschr., $19 \circ 3$, p. 89 et seq.

108. Wittrock ('78) : V. B. Wittrock, Oedogonieae Americanae, hucusque cognitae. Bot. Notiser, I 878 , pp. I $33-45$.

109. Zanardini ('72): J. Zanardini, Phycearum indicarum pugillus a cl. Eduardo Beccari ad Borneum, Singapoore et Ceylanum annis $1865^{-7}$ collectarum. Mem. d. Reale Istit. Veneto, xvii, 1872 , p. I29 et seq.

110. Zeller ('73*): G. Zeller, Algae collected by Mr. S. Kurz in Arracan and British Burma. Journ. Asiat. Soc. Bengal, xlii, 1873, pp. I 75-93 ; also Hedwigia, I873, p. 168 et seq.

111. ('76): G. Zeller, Algae Brasilienses circa Rio de Janeiro a Dr. A. Glaziou, horti publici directore, collectae. Vid. Meddelels. Nat. Foren. i Kjфbenhavn, 1876, p. 426 et seq. 


\section{$2 \mathrm{BHL}$ Biodiversity Heritage Library}

Fritsch, Felix Eugene. 1907. "The subaerial and freshwater algal flora of the tropics." Annals of botany 21, 235-275.

https://doi.org/10.1093/oxfordjournals.aob.a089132.

View This Item Online: https://www.biodiversitylibrary.org/item/235747

DOI: https://doi.org/10.1093/oxfordjournals.aob.a089132

Permalink: https://www.biodiversitylibrary.org/partpdf/318871

\section{Holding Institution}

Smithsonian Libraries

\section{Sponsored by}

Biodiversity Heritage Library

\section{Copyright \& Reuse}

Copyright Status: Not in copyright. The BHL knows of no copyright restrictions on this item.

This document was created from content at the Biodiversity Heritage Library, the world's largest open access digital library for biodiversity literature and archives. Visit BHL at https://www.biodiversitylibrary.org. 